\title{
GEOCHEMISTRY AND MINERALOGY OF GOLD-RICH HYDROTHERMAL PRECIPITATES FROM THE EASTERN MANUS BASIN, PAPUA NEW GUINEA
}

\author{
ROGER MOSS ${ }^{\S}$ AND STEVEN D. SCOTT \\ Scotiabank Marine Geology Research Laboratory, Department of Geology, University of Toronto, 22 Russell Street, \\ Toronto, Ontario, Canada M5S $3 B 1$
}

\begin{abstract}
Three of the five hydrothermal vent fields currently known in the Manus back-arc basin of Papua New Guinea are enriched in gold. Samples of precipitates from the PACMANUS and Susu Knolls hydrothermal fields in eastern Manus Basin contain up to $56.8 \mathrm{ppm}$ gold, and average $11.3 \pm 13(1 \sigma) \mathrm{ppm}(n=103)$. Chimney samples dominated by sphalerite, barite and chalcopyrite have significantly higher contents of gold than sulfide-poor samples. Gold in the sulfide chimneys occurs as micrometric grains of silver-poor (1.4 to $4.2 \mathrm{wt} . \% \mathrm{Ag}$ ) native gold in three distinct associations. In copper-rich chimney samples, gold occurs as inclusions in chalcopyrite associated with tennantite, bornite and covellite. In zinc-rich chimney samples, gold is present mainly as inclusions in tennantite associated with chalcopyrite and sphalerite. A high activity of sulfur is indicated for the gold-rich eastern Manus Basin precipitates by the sulfide assemblages, the low iron content of sphalerite (average $=2.3 \pm 3$ mole $\% \mathrm{FeS}$ ), and the silver-poor nature of gold grains. Evaluation of possible complexes of gold indicates that AuHS ${ }^{\circ}$ is the dominant complex, which is consistent with the high activity of sulfur in the hydrothermal system. According to available experimental data, $\mathrm{AuHS}^{\circ}$ is the dominant complex up to $325^{\circ} \mathrm{C}$. This complex thus is the only one required for gold enrichment in both the $\mathrm{Zn}-\mathrm{Au}$ and the $\mathrm{Cu}-\mathrm{Au}$ associations. Gold transport as the AuHS ${ }^{\circ}$ complex is likely to be equally important in other seafloor hydrothermal systems with acidic end-member hydrothermal fluids.
\end{abstract}

Keywords: hydrothermal, gold, vent, seafloor, massive sulfide, PACMANUS vent field, Papua New Guinea.

\section{SOMMAIRE}

Trois des cinq champs d'évents hydrothermaux connus dans l'arrière-arc du bassin de Manus, en Papouasie Nouvelle Guinée, montrent un enrichissement en or. Les échantillons des précipités provenant des champs hydrothermaux de PACMANUS et de Susu Knolls, dans le secteur oriental du bassin de Manus, contiennent jusqu'à 56.8 ppm d'or, et atteignent en moyenne $11.3 \pm 13$ $(1 \sigma) \operatorname{ppm}(n=103)$. Les échantillons de cheminées à prédominance de sphalérite, barite et chalcopyrite contiennent des teneurs en or nettement plus élevées que les échantillons à faible teneur en sulfures. L'or des cheminées sulfurées se présente sous forme de grains micrométriques d'or natif à faible teneur en argent (de 1.4 à $4.2 \% \mathrm{Ag}$, poids), en trois associations distinctes. Dans les échantillons de cheminées riches en cuivre, l'or se présente sous forme d'inclusions dans la chalcopyrite associée à la tennantite, la bornite et la covellite. Dans les échantillons de cheminées riches en zinc, l'or se présente surtout sous forme d'inclusions dans la tennantite associée à la chalcopyrite et la sphalérite. Dans le secteur oriental du bassin de Manus, une activité élevée en soufre serait indiquée pour expliquer ces précipités aurifères associés à des assemblages riches en sulfures, la faible teneur en fer de la sphalérite (en moyenne $2.3 \pm 3 \% \mathrm{FeS}$, base molaire), et la faible teneur en argent des grains d'or. Une évaluation des complexes potentiels pour transporter l'or montre que $\mathrm{AuHS}^{\circ}$ est le plus important, ce qui concorde avec l'activité accrue du soufre dans le système hydrothermal. Selon les données expérimentales disponibles sur la stabilité de ces complexes, AuHS ${ }^{\circ}$ serait prédominant jusqu'à $325^{\circ} \mathrm{C}$. Il serait donc le seul requis pour expliquer l'enrichissement en or à la fois dans les associations $\mathrm{Zn}-\mathrm{Au}$ et $\mathrm{Cu}-\mathrm{Au}$. Le transfert de l'or sous forme du complexe AuHS ${ }^{\circ}$ serait également important dans d'autres milieux d'évents hydrothermaux dont les fluides s'approchent du pôle acide.

(Traduit par la Rédaction)

Mots-clés: hydrothermal, or, évent, fonds marins, sulfures massifs, champ d'évents PACMANUS, Papouasie Nouvelle Guinée.

§ E-mail address: roger_moss@sympatico.ca 


\section{INTRODUCTION}

Exploration of the modern seafloor over the past two decades has resulted in the discovery of many areas of hydrothermal activity in geographically and tectonically diverse settings. Initial work between 1977 and 1985 concentrated on the investigation of vent sites on the mid-ocean ridges of the East Pacific, and on the MidAtlantic Ridge. Hydrothermal precipitates from several of these ocean-ridge deposits were found to be enriched in gold (Hannington \& Scott 1988, 1989a, Hannington et al. 1986, 1991), although such gold-rich precipitates are not typical of the majority of ocean-ridge deposits.

More recently, attention has turned to the submarine arcs and marginal basins of the western Pacific. This exploration has resulted in the identification of more than 27 hydrothermal sites (Ishibashi \& Urabe 1995) ranging in water depth from the shallow-water $(\sim 200 \mathrm{~m})$ Whakatane vent site south of White Island, New Zealand (Hannington et al. 1999) to the 3,700meter-deep Alice Spring site in the central Mariana Trough (Craig et al. 1987a). Many of the precipitates associated with these vent sites are extremely gold-rich, with values up to $71 \mathrm{ppm} \mathrm{Au}$ (average $28 \mathrm{ppm}, n=11$ ) reported for sulfides from the Suiyo Seamount on the Izu-Bonin arc (Watanabe \& Kajimura 1994), and up to $49 \mathrm{ppm} \mathrm{Au}$ (average $20 \mathrm{ppm}, n=37$ ) from the Sunrise Deposit, $400 \mathrm{~km}$ to the south (Iizasa et al. 1999). Clearly, the prolific gold mineralization found on land in the volcanic arcs of the region (Sillitoe 1989) continues into the submarine arcs, forearcs and back-arc basins associated with these subaerial environments.

Our understanding of the processes involved in the enrichment of gold in volcanogenic massive sulfide deposits has been shaped by complementary studies on both the modern seafloor (e.g., Hannington \& Scott 1989a, b, Hannington et al. 1991, 1995, Herzig et al. 1993) and ancient deposits on land (e.g., Huston \& Large 1989, Hutchinson 1990, Large 1990, Huston et al. 1992). In this study of gold-rich precipitates from the eastern Manus Basin, Papua New Guinea, we describe the geochemistry and mineralogy of gold in hydrothermal precipitates from the PACMANUS and Susu Knolls vent fields, two of the most gold-rich back-arc basin deposits of the western Pacific.

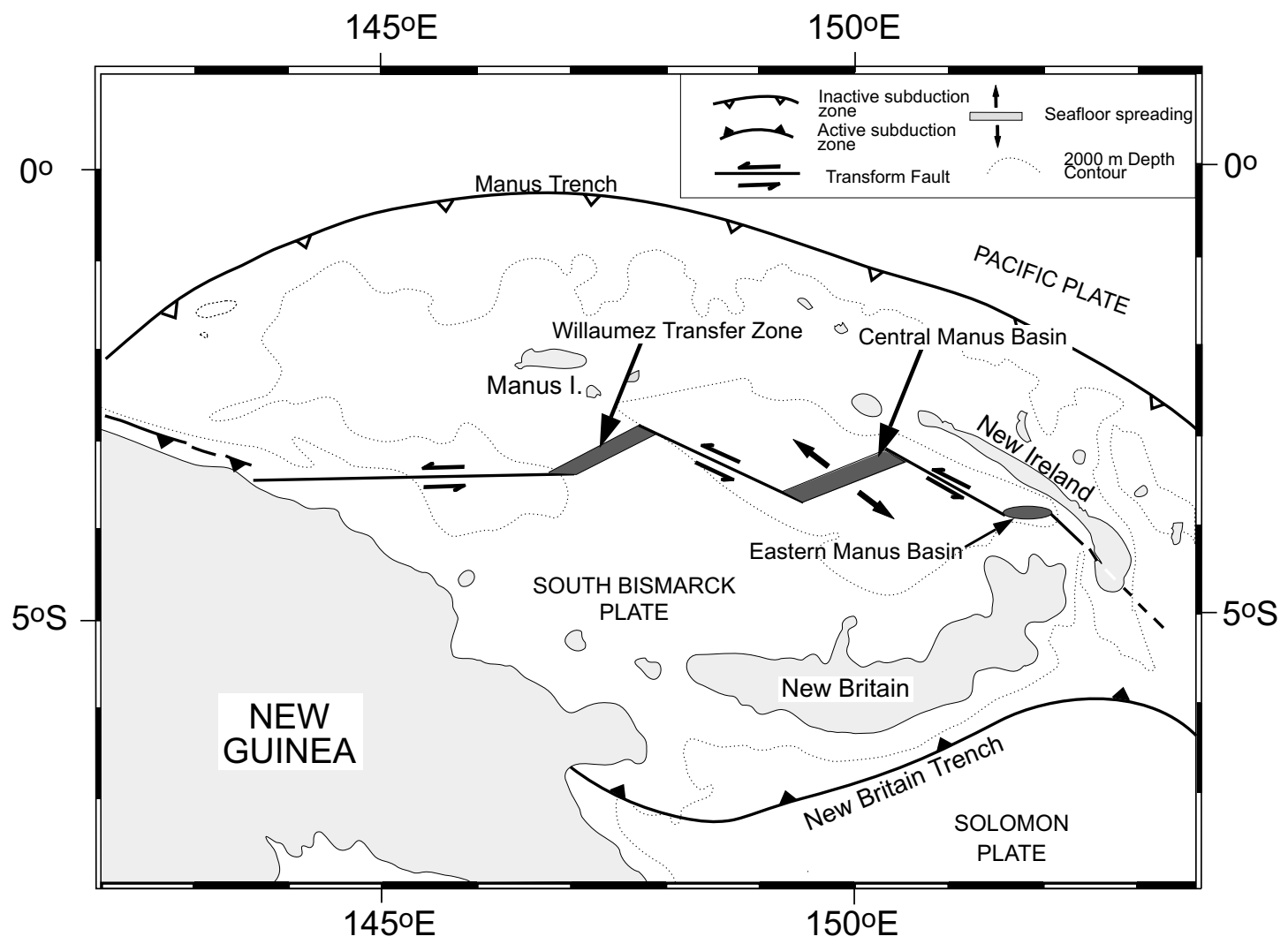

FIG. 1. Main tectonic elements of the Manus Basin region (modified from Benes et al. 1994). 


\section{Geological Setting}

The Manus Basin is the back-arc of the active New Britain volcanic arc, situated to the east of the island of New Guinea (Fig. 1). Subduction began under New Britain after earlier subduction along the Manus trench stopped in the Oligocene owing to the effect of the Ontong Java Plateau docking against the Manus trench (Martinez \& Taylor 1996). Back-arc spreading occurs along the central Manus spreading center, decreasing from $92 \mathrm{~mm} /$ year (full rate) in the southwestern end of the spreading center to $0 \mathrm{~mm} / \mathrm{year}$ in the northeast (Martinez \& Taylor 1996). Eastern Manus Basin is a pull-apart structure that consists of a series of en échelon volcanic ridges between two transform faults within thinned arc crust (Binns \& Scott 1993). Development of this structure is believed to have been contemporaneous with that of the Bismarck microplate (Martinez \& Taylor 1996).

Four active vent fields and one inactive field have been discovered in Manus Basin, three of which occupy an area of approximately $4,000 \mathrm{~km}^{2}$ in the eastern Manus Basin (Binns et al. 1997). The inactive deposit is located on the Willaumez transfer zone, and consists primarily of iron oxide mounds (Binns 1994). The Vienna Woods hydrothermal field occurs at a depth of 2,500 meters on the central Manus spreading center. The first reports of hydrothermal activity in the region resulted from deep camera tows, which photographed vent fauna and inactive chimneys (Both et al. 1986). Active hydrothermal venting was discovered on the central Manus spreading center during the OLGA II research cruise of the RV Sonne (Tufar 1990). Both black and white smoker chimneys with abundant vent fauna were found. The vent field consists predominantly of zincrich chimneys, venting $285^{\circ}$ to $300^{\circ} \mathrm{C}$ fluid, sitting atop a sulfide mound, with fewer anhydrite-rich chimneys sitting directly on the seafloor (Auzende et al. 1996a, b). Hydrothermal precipitates are enriched in zinc sulfide (sphalerite and wurtzite) and silica with an average base-metal content of $29.7 \% \mathrm{Zn}, 2.2 \% \mathrm{Cu}$ and $0.6 \% \mathrm{~Pb}$ $(n=25$, Tufar 1990). These sulfides also are enriched in gold (average $30 \mathrm{ppm}$ ) and silver, which ranges from $25 \mathrm{ppm}$ to $1036 \mathrm{ppm}$ (Binns 1994).

The discovery of $\mathrm{CH}_{4}$ and ${ }^{3} \mathrm{He}$ anomalies in the water column (Craig \& Poreda 1987, Craig et al. 1987b) was the first indication of hydrothermal activity in the eastern part of Manus Basin. Subsequently, three main vent fields, DESMOS, Susu Knolls and PACMANUS, were found in the region. DESMOS is a cauldron within basaltic andesite over which a large methane and manganese plume was discovered in 1990 (Sakai 1991, Gamo et al. 1993). Low-temperature $\left(118^{\circ} \mathrm{C}\right)$, acidic $(\mathrm{pH}=2.1)$, vigorous venting is associated with a fault in the northwest wall of the cauldron (Auzende et al. 1996a, b). This vent site, named Onsen (Fig. 2), is characterized by a high sulfate content in the vent fluid and the deposition of abundant native sulfur (Gamo et al. 1997). Mineralization consists of enargite and pyrite associated with alunite (Gena et al. 1998), suggesting similarities with the subaerial to shallow submarine high-sulfidation deposits described by Hannington et al. (1999).

The Susu Knolls vent field, discovered during the 1996 PACMANUS III expedition in the eastern part of the eastern Manus Basin, is situated on a northwestsoutheast-trending andesitic ridge named Tumai Ridge. The vent field consists of clusters of vigorously active chimneys on the tops of two coalesced porphyritic dacite domes (North Su and South Su), and an adjacent site of chimneys and massive sulfides known as Suzette (Fig. 2). The mineralization at Suzette is particularly

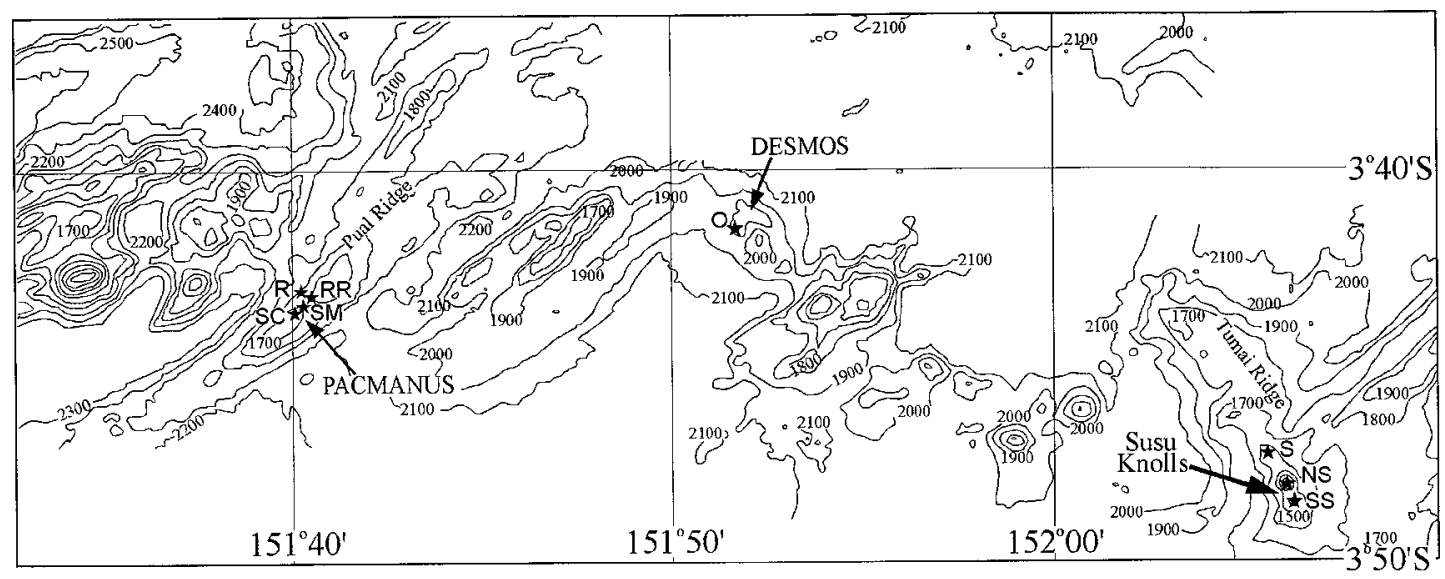

FIG. 2. Simplified bathymetric map of eastern Manus Basin (after Sakai 1991) showing location of vent sites (stars). Abbreviations: R Rogers Ruins, RR Roman Ruins, SC Snowcap, SM Satanic Mills, O Onsen, S Suzette, NS North Su, SS South Su. 
copper-rich, with an average of $19 \% \mathrm{Cu}$ reported from three chimneys. The three samples reported to date also have high contents of zinc (average 22\%), silver (average $125 \mathrm{ppm}$ ) and gold (average $23 \mathrm{ppm}$ ) (Binns et al. 1997).

The PACMANUS vent field was discovered in 1991 (Binns \& Wheller 1991), underlying a strong Mn anomaly in the water column (Sakai 1991). It is situated near the bathymetric minimum of a northeast-southwest-trending ridge named Pual Ridge, which is composed of andesite, dacite and rhyolite. Andesite dominates the lower reaches of the 500-meter-high ridge, whereas the crest is predominantly dacite and rhyolite (Binns \& Scott 1993, Scott \& Binns 1995). Detailed investigations of the area by deep-tow camera and video (Binns \& Wheller 1991, Binns \& Scott 1993) and submersible (Auzende et al. 1996a, b) revealed four discrete vent-sites (Fig. 2), separated by areas of intermittent hydrothermal activity in the form of iron-manganese oxides and low-temperature shimmering vents. This hydrothermal activity covers an area of approximately $1100 \times 600$ meters on the crest of Pual Ridge.

The Rogers Ruins vent site, located at the northern edge of the ridge crest, consists of actively venting black smokers up to 7.5 meters high, together with inactive chimneys. Active chimneys have complex shapes, many with peripheral spires growing around a dominant central structure. Samples from the vent field are dominantly zinc-rich with iron oxide coatings. Immediately to the east of the vent field, numerous small (approximately one meter diameter) mounds of iron and manganese oxides are venting clear, low-temperature $\left(40^{\circ} \mathrm{C}\right)$ fluid.

The Roman Ruins vent site lies approximately 250 meters to the south of Rogers Ruins, and consists of numerous large (up to 20 meters high and 3 meters in diameter) predominantly inactive chimneys. Many such chimneys appear to have coalesced to form a chimney "wall", with active venting of clear hydrothermal fluid from small chimneys and fissures on ledges in this "wall".

Coalesced chimney structures venting high temperature (up to $268^{\circ} \mathrm{C}$ ) fluid through small "chimneylets" are characteristic of the Satanic Mills site. In contrast to samples collected from Roman Ruins and Rogers Ruins, those from Satanic Mills tend to be copper-rich.

The fourth vent site, Snowcap, covers a knoll of altered dacite-rhyolite and is characterized by low-temperature diffuse venting and abundant white bacterial mat associated with altered hyaloclastite (Binns et al. 1997). Active chimneys with beehive-type diffuser tops (cf. Fouquet et al. 1993) are located immediately south of this site.

\section{Analytical Techniques}

A total of 103 chimney samples and sub-samples were analyzed during this study. Samples were recov- ered by dredging during three RV Franklin cruises (PACMANUS II, III and IV) and by Shinkai 6500 submersible during the 1995 Manusflux cruise. Concentrations of copper, lead, silica and calcium were obtained by X-ray fluorescence (XRF), of sulfur by the LECO infrared spectrometry technique, and of bismuth, tellurium and selenium by hydride generation followed by inductively coupled plasma - atomic emission spectrometry (ICP-AES), all at Activation Laboratories, Ancaster, Ontario. Concentrations of the remaining elements reported here, including gold, were established by instrumental neutron activation analysis (INAA) at the University of Toronto. Details of the analytical procedure are given in Moss \& Scott (1996).

Analyses of gold and sphalerite were carried out using a Cameca SX-50 electron microprobe. A synthetic gold-silver alloy ("electrum") standard with 20 at. $\% \mathrm{Ag}$ was used to analyze for gold and a synthetic sphalerite standard containing 20 at.\% Fe was used for the sphalerite analyses. Repeat analyses of these standards indicate relative precisions [(standard deviation/mean $) \times 100]$ of $2 \%$ for $\mathrm{Au}, 3 \%$ for $\mathrm{Ag}, 0.3 \%$ for $\mathrm{Zn}, 0.7 \%$ for $\mathrm{Fe}$ and $0.1 \%$ for S. X-ray powder diffraction was performed at the Department of Chemistry, University of Toronto, with a Siemens D5000 diffractometer operating at $50 \mathrm{kV}, 35 \mathrm{~mA}$.

\section{Bulk Composition of Hydrothermal Precipitates}

The samples analyzed during this study include hydrothermal precipitates from the four PACMANUS vent sites and the three sites in the Susu Knolls area (Table 1). The gold content of the precipitates ranges from below detection (approximately $4 \mathrm{ppb}$ ) to $56.8 \mathrm{ppm}$ and averages $11.3 \mathrm{ppm}$ (Table 2). Precipitates from Roman Ruins (average 17.2 $\pm 13 \mathrm{ppm} \mathrm{Au}, n=37$ ), Susu Knolls (average $14.8 \pm 18 \mathrm{ppm} \mathrm{Au}, n=9$ ) and Satanic Mills (average $13.3 \pm 11 \mathrm{ppm} \mathrm{Au}, n=25$ ) are clearly more gold-rich than those from Snowcap (average $2.3 \pm 3$ ppm Au, $n=13$ ) and Rogers Ruins (average $1.3 \pm 4$ ppm Au, $n=18$ ) (Fig. 3a). This difference in gold content is reflected in the mineralogical composition of the precipitates, which is controlled by the physical and chemical characteristics of the hydrothermal fluid. Temperatures of the vent fluid measured during the ManusFlux Cruise averaged $245^{\circ} \mathrm{C}$ at the Satanic Mills vent site, and $160^{\circ} \mathrm{C}$ at Roman Ruins (Auzende et al. 1996b, Gamo et al. 1997). Higher temperatures, up to $285^{\circ} \mathrm{C}$, were measured for the Susu Knolls vent sites during the 2000 Manaute Cruise (Y. Fouquet, pers. commun., 2000), consistent with the more copper-rich nature of samples from the Suzette vent site than those from the PACMANUS area.

Samples to be analyzed were selected to represent the range of mineralogical types occurring in the region, and were distinguished according to their dominant mineral assemblage. Oxidized chimneys rich in iron oxide and silica from the Rogers Ruins vent site at 
TABLE 1. DESCRIPTION OF SULFIDE SAMPLES FROM VARIOUS VENT-SITES IN THE EASTERN MANUUS BASIN

\section{Satanic Mills}

297-S-2A Piece of black smoker chimney, actively venting $220^{\circ} \mathrm{C}$ fluid when sampled, with numerous chalcopyrite-lined orifices and a thin $\mathrm{Fe}-$ oxide exterior crust.

297-S-2B Two pieces of chimney from same area as 2A. Chalcopyrite-lined conduits are common. Some conduits are lined by sphalerite.

297-S-5 Pieces of sphalerite-rich chimney, with chalcopyrite-lined conduits.

301-S-01 Inactive chimney near a $250^{\circ} \mathrm{C}$ black smoker. Massive chalcopyrite, sphalerite and pyrite clog two orifices, and one has an iron oxide coating. The chimney exterior has a thin layer of Fe-oxide covered by manganese oxide.

301-S-02 Inactive chimney sampled near a $268^{\circ} \mathrm{C}$ black smoker. Interior consists of three coalesced orifices lined with euhedral coarse-grained sphalerite.

118310 Crusts rich in iron oxide and manganese oxide on hyaloclastite

$118355 \mathrm{C}$ Zoned chalcopyrite-barite-sphalerite piece.

118553 Piece of chimney rich in sphalerite and Fe-oxide.

$118554 \mathrm{~A}$ Bottom of sphalerite-rich chimney.

$118554 \mathrm{~B}$ Sphalerite-rich piece of chimney.

$118555-2$ to 7 Cross-sections through a sphalerite-rich chimney

$118556 \mathrm{C}-1$ Chalcopyrite-rich inner zone of zoned chimney.

$118556 \mathrm{C}-2$ Outer zone of chimney, rich in sphalerite and barite.

118565 Piece of chimney rich in Fe-oxide and barite.

118567 Zoned chalcopyrite - Fe-oxide piece of chimney.

118584A-1 Chalcopyrite-rich otifice.

$118584 \mathrm{~A}-2$ Sphalerite-rich piece of chimney

$118584 \mathrm{~A}-3$ Zoned piece from chalcopyrite-rich interior to Fe-oxide exterior.

$118584 \mathrm{~B} 1 \mathrm{~A}$ Massive chalcopyrite (to $1 \mathrm{~cm}$ ) occurs around a small ( $1 \mathrm{~cm}$ diameter) orifice in the chalcopyrite-rich portion of chimney, with some sphalerite near exterior.

$118587 \mathrm{D}$ Piece of chimney rich in sphalerite and barite

132450 Section through a chalcopyrite-rich chimney with clogged orifices 1 to $5 \mathrm{~mm}$ in diameter.

132451 Section through chimney rich in pyrite and sphalerite.

132452 Piece of sphalerite-rich chimney.

132453 Piece of chalcopyrite-rich chimney.

132453-1 Basal section of chalcopyrite-rich chimney.

\section{Rogers Ruins}

132557

$132557-$

$132557-2$

$132557-3$

$132557-4$

132579

132649

132651

$132651-$

$132651-2$

132652

132720

132740

132744

133990

134293

134296

Portion of sphalerite-barite rich chimney with minor iron oxide. Sphalerite-barite-rich piece of chimney

Inner chimney wall

Inner middle chimney wall.

Outer middle chimney wall.

Exterior chimney wall

Silica - iron oxide-rich piece of chimey.

Silica - iron oxide-rich piece of chimney.

Piece of iron oxide mound with a thin manganese-oxide-rich exterior. Manganese-oxide-rich exterior part of mound

Iron-oxide-rich interior part of iron-manganese oxide mound.

Sphalerite-barite-rich piece of chimney flange.

Iron-oxide-rich precipitate with manganese oxide coating

Iron-oxide-rich sample with minor manganese oxide crust.

Fragment of oxidized chimney dominated by iron oxide

Iron-oxide-rich crust.

Cross section through a sphalerite-barite-rich piece of chimney.

Portion of beehive-type diffuser, with alternating sphalerite and silicarich layers.

\section{Suzette}

132807-1 Chalcopyrite-barite-rich inner portion of zoned chimney.

132807-2 Sphalerite-barite-rich outer portion of chimney with a thin iron oxide coating

133012 Chalcopyrite-rich chimney with a thin (1 to $2 \mathrm{~mm}$ thick) sphalerite rim covered by iron oxide and a large central orifice filled with sphalerit and barite. 133016 Section through a sphalerite-rich composite chimney with three orifices

133021 Zoned chimney with an interior chalcopyrite-rich zone (1-5 mm), a middle sphaterite-rich zone $(5-15 \mathrm{~mm})$ and an outer iron-oxide atacamite zone $(0.5-1 \mathrm{~mm})$.

\section{North Su}

\section{Roman Ruins}

301-S-03 Small pieces of sphalerite-rich chimney with a massive sphalerite interior and a thin layer of Fe-oxide on the exterior.

304-S-01 Chimney pieces from a small active diffuser venting clear $179^{\circ} \mathrm{C}$ fluid Samples have a sphalerite-rich interior, with some pyrite, and an iron oxide exterior coating.

132376

Chimney fragment with a massive chalcopyrite interior and a thin $(<1$ $\mathrm{cm})$ sphalerite-rich exterior covered by a 1 -mm-thick Fe-oxide layer

132616-1 Chalcopyrite-rich central portion of a zoned chimney

132616-2 Sphalerite-rich portion of zoned chimney.

132616-3 Mixed chalcopyrite- sphalerite central orifice of chimney.

132620 Zoned chalcopyrite - sphalerite - iron oxide chimney.

132620-1 Middle sphalerite-rich piece.

132620-2 Exterior iron-oxide-rich piece.

132620-4 Middle sphalerite-rich piece.

132620-5 Interior massive chalcopyrite piece.

132620-6 Interior massive chalcopyrite piece.

132620-7 Interior massive chalcopyrite piece.

132620-8 Interior mixed chalcopyrite-sphalerite.

132620-9 Interior massive chalcopyrite.

132620-10 Middle sphalerite-rich piece.

132620-11 Chalcopyrite-rich orifice rim

132620-12 Middle sphalerite-rich piece.

132620-13 Exterior iron-oxide rich piece.

132620-14 Middle sphalerite-rich piece

132620-15 Middle sphalerite-rich piece.

132620-16 Middle sphalerite-rich piece

132620-17 Massive chalcopyrite rim of secondary orifice.

132620-18 Exterior chalcopyrite-sphalerite-rich piece.

132620-19 Exterior chalcopyrite-rich piece.

132620-20 Exterior sphalerite-rich piece.

132620-21 Exterior sphalerite-rich piece.

132621 Section through a chalcopyrite-rich chimney with a thin sphalerite and iron-oxide-rich exterior wall.

132625 Chalcopyrite-sphalerite zoned chimney with an iron oxide exterior.

132974 Sphalerite-barite-rich flange-type chimney piece with an iron oxide exterior

132982 Sphalerite-pyrite-rich chimney with an iron oxide exterior.

$133990 \quad$ Fe-oxide crust

134067-1 Sphalerite - barite - iron oxide-rich exterior piece of chimney.

134067-2 Sphalerite-barite-rich interior piece of chimney.

134228

134237

134238 Chalcopyrite-rich piece of chimney with a small arifice. Chalcopyrite-rich piece of chimney.

Zoned chalcopyrite - sphalerite - iron oxide piece of chimney.

\section{Snoweap}

305-S-01 Top of a dead chimney, with a massive sphalerite, anhydrite interior and an iron oxide - manganese oxide exterior.

118303

$118303 \mathrm{~A}$

118310

132381

132382

132400

132497

132603

134078

134092

134191

134192

Piece of pyrite-covellite-bornite-rich mushroom-shaped chimney.

Exterior piece of mushroom-shaped chimney.

ter-manganese oxide crust on altered hyaloclastite.

Piece of sphalerite-rich chimney flange with thin iron oxide exterior Sphalerite-rich piece of chimney, with minor iron oxide Sphalerite - iron oxide-rich piece of chimney. Sphalerite lines a clogged orifice.

Hyaloclastite composed of volcanic fragments 2 to $5 \mathrm{~mm}$ across cemented by very fine-grained pyrite.

Hyaloclastite cemented by pyrite, minor native sulfur

Iron-oxide-rich mound sample.

Iron-oxide-rich mound sample.

Manganese-rich piece of hydrothermal crust.

Manganese-rich piece of hydrothermal crust.

South Su

133832 Pyrite-bornite-rich crust.

133834 Pyrite-rich hyaloclastite.

\section{Nimab}

$132689 \quad$ Sulfidic mud. 
TABLE 2. SUMMARY OF THE COMPOSITION OF HYDROTHERMAL PRECIPITATES, EASTERN MANUS BASIN

\begin{tabular}{|c|c|c|c|c|c|c|c|c|c|c|c|c|c|c|c|c|c|c|c|c|}
\hline Vent site & SM & $\mathrm{SC}$ & $\mathbf{R}$ & $\mathbf{R R}$ & $\mathbf{S}$ & $\mathrm{SC}$ & RR & SM & RR & $\mathrm{S}$ & SM & RR & $\mathrm{S}$ & NS & SM & $\mathrm{SC}$ & $\mathbf{R}$ & SS & $\mathbf{R R}$ & $\mathbf{N}$ \\
\hline Type & \multicolumn{5}{|c|}{ Sphalerite--barite } & \multicolumn{2}{|c|}{$\mathrm{Sp}-\mathrm{Gn}$} & \multicolumn{3}{|c|}{$\mathrm{Sp}-\mathrm{Ccp}$} & \multicolumn{4}{|c|}{ Chalcopyrite } & \multicolumn{6}{|c|}{ Sulfide-poor } \\
\hline $\mathbf{n}$ & 17 & 3 & 10 & 20 & 1 & 1 & 1 & 3 & 10 & 1 & 4 & 6 & 3 & 2 & 2 & 7 & 8 & 2 & 1 & 1 \\
\hline $\mathrm{SiO}_{2}$ wt $\%$ & 2.41 & 8.10 & 5.10 & 2.80 & 1.01 & 2.66 & 0.35 & 0.08 & 7.15 & 1.37 & 0.54 & 5.68 & 3.54 & 1.51 & 0.18 & 13.69 & 62.25 & 25.06 & 37.63 & 75,28 \\
\hline $\mathrm{CaO}$ & 0.11 & 0.05 & 0.14 & 0.11 & 0.46 & 0.07 & 0.09 & 0.09 & 0.10 & 0.16 & 8.19 & 0.07 & 0.73 & 0.08 & 37.59 & 0.61 & 0.37 & 0.16 & 0.54 & 0.28 \\
\hline $\mathrm{Fe}_{2} \mathrm{O}_{3}$ & 8.87 & 0.91 & 3.76 & 15.08 & 19.56 & 0.07 & 14.66 & 35.75 & 22.98 & 23.65 & 38.92 & 38.18 & 36.64 & 34.21 & 4.00 & 23.58 & 13.03 & 32.74 & 40.78 & 9.67 \\
\hline $\mathrm{Na}_{2} \mathrm{O}$ & 0.47 & 0.19 & 0.52 & 0.76 & 1.28 & 0.34 & 0.78 & 0.25 & 0.87 & 0.34 & 0.16 & 0.13 & 0.28 & 1.14 & 0.02 & 3.30 & 2.46 & 0.56 & 2.97 & 3.58 \\
\hline $\mathrm{Cu}$ & 2.79 & 1.10 & 0.55 & 3.88 & 3.93 & 0.09 & 1.20 & 10.00 & 16.89 & 8.21 & 25.14 & 28.51 & 26.98 & 13.59 & 0.45 & 0.11 & 0.04 & 1.57 & 0.01 & 0.02 \\
\hline $\mathrm{Zn}$ & 37.53 & 48.33 & 35.24 & 32.30 & 6.45 & 48.00 & 21.30 & 9.92 & 22.31 & 3.46 & 2.31 & 3.96 & 0.54 & 0.24 & 0.05 & 0.10 & 0.39 & 0.04 & 0.09 & 0.15 \\
\hline $\mathrm{Pb}$ & 1.92 & 2.05 & 1.36 & 2.37 & 1.14 & 17.62 & 8.17 & 1.08 & 1.47 & 0.55 & 0.09 & 0.28 & 0.09 & 0.02 & 0.01 & 0.05 & 0.11 & 0.04 & 0.05 & 0.20 \\
\hline $\mathrm{Ba}$ & 11.45 & 3.60 & 19.54 & 7.84 & 26.64 & 2.20 & 13.65 & 6.67 & 1.73 & 23.22 & 0.15 & 0.65 & 5.13 & 5.44 & 0.29 & 0.03 & 1.11 & 0.18 & 0.15 & 0.25 \\
\hline $\mathbf{S}$ & 26.75 & 25.50 & 24.16 & 31.58 & 25.6 & 28.1 & 30.1 & 41.40 & 31.77 & 27.40 & 37.40 & 32.60 & 31.10 & 35.80 & na & 7.62 & 0.78 & 40.70 & 0.20 & 0.40 \\
\hline Mo ppm & 15 & 18 & 6 & 51 & 149 & 4 & 58 & 46 & 108 & 148 & 159 & 285 & 206 & 3 & 8 & 346 & 186 & 12 & 21 & 23 \\
\hline $\mathrm{Hg}$ & 17 & 42 & 13 & 8 & 43 & 2 & 59 & 12 & 7 & 18 & 10 & 8 & 4 & 30 & 1 & 1 & 2 & 18 & 1 & 1 \\
\hline $\mathrm{Au}$ & 16.58 & 0.06 & 2.27 & 21.18 & 20.49 & 0.04 & 13.05 & 10.50 & 22.82 & 23.90 & 8.12 & 6.72 & 25.54 & 45.51 & 0.12 & 0.41 & 0.10 & 0.44 & 0.12 & 0.03 \\
\hline $\mathrm{Ag}$ & 283 & 975 & 509 & 352 & 296 & 924 & 2031 & 49 & 282 & 211 & 72 & 86 & 102 & 38 & 1 & 12 & 5 & 33 & 1 & 2 \\
\hline As & 7558 & 3359 & 4333 & 5451 & 7139 & 11956 & 4167 & 8093 & 6668 & 2386 & 1899 & 1795 & 722 & 43481 & 31 & 589 & 1682 & 5640 & 3262 & 1507 \\
\hline $\mathrm{Sb}$ & 1049 & 296 & 720 & 842 & 1092 & 100 & 2978 & 370 & 931 & 426 & 208 & 216 & 116 & 841 & 1 & 13 & 95 & 206 & 27 & 112 \\
\hline $\mathrm{Cd}$ & 1354 & 1644 & 1401 & 1521 & 664 & 1032 & 619 & 166 & 1089 & 278 & 81 & 213 & 38 & 17 & 2 & 6 & 10 & 17 & 6 & 4 \\
\hline Co & 2 & 4 & 2 & I & 52 & 2 & 1 & 58 & 2 & 107 & 38 & 2 & 162 & 5 & 85 & 3 & 3 & 6 & 1 & na \\
\hline $\mathrm{Bi}$ & 12 & 1 & $<1$ & $<1$ & 1 & $<1$ & $<1$ & 29 & 11 & $<1$ & 42 & $<1$ & 93 & 1 & 9 & 1 & $<1$ & 4 & $<1$ & $<1$ \\
\hline $\mathrm{Ge}$ & 59 & 11 & 8 & 20 & 1 & 11 & 6 & 8 & 39 & 1 & 1 & 8 & 1 & 2 & na & 2 & 3 & 4 & 3 & 1 \\
\hline $\mathrm{Se}$ & 2 & 2 & $<1$ & 6 & 5 & $<1$ & 1 & 92 & 13 & 4 & 107 & 26 & 66 & 56 & 20 & 1 & 1 & 38 & $<1$ & $<1$ \\
\hline $\mathrm{Te}$ & 2 & 1 & 1 & 2 & 1 & $<1$ & 1 & 26 & 6 & 4 & 47 & 17 & 24 & 53 & 18 & 3 & 1 & 25 & $<1$ & 1 \\
\hline
\end{tabular}

Abbreviations: SM Satanic Mills, RR Roman Ruins, R Rogers Ruins, SC Snowcap, S Suzette, SS South Su, NS north Su, N Nimab, na not analyzed, $\mathrm{n}$ : number of samples, Sp sphalerite, Gn galena, $\mathrm{Ccp}$ chalcopyrite. Sample types are described in the text. Descriptions of individual samples are given in Table 1.

PACMANUS typically contain little gold (Fig. 3b). Similarly, iron-manganese oxide crusts and mounds and iron oxide chimneys are gold-poor. The sphalerite barite-rich, predominantly inactive chimneys from the Roman Ruins vent sites are enriched in gold, as are the zoned chalcopyrite-sphalerite chimneys from the Satanic Mills and Susu Knolls areas. Massive chalcopyrite-rich chimneys, or chalcopyrite-rich portions, are variably enriched in gold, with one sample from the Susu Knolls area having the highest gold content encountered, $56.8 \mathrm{ppm}$ (Fig. 3b). The concentration of gold shows statistically significant (at the $95 \%$ confidence level) positive correlations with that of $\mathrm{Zn}, \mathrm{Cu}, \mathrm{S}$, $\mathrm{Sb}$ and $\mathrm{Cd}$, (Figs. 4a-e). A significant negative correlation of Au with $\mathrm{SiO}_{2}$ (Fig. 4g) is consistent with the low gold content of sulfide-poor samples in the area.

There is no unique position of gold enrichment within zoned chimneys from eastern Manus Basin, as both interior (Cu-rich) and exterior ( $\mathrm{Zn}$-rich) chimney portions contain high $(>1 \mathrm{ppm})$ values of gold (Fig. 5). However, zinc-rich portions generally have the higher gold contents. One complexly zoned chimney selected for detailed analysis has a broad zone of gold enrichment in the Zn-rich middle chimney wall (Fig. 6). Analysis of sub-samples from a zoned chimney from Lau Basin produced a similar result (Herzig et al. 1993).

\section{Mineralogy of Hydrothermal Precipitates}

\section{Sphalerite + barite samples}

These samples consist predominantly of porous aggregates of sphalerite and prismatic crystals of barite that fill cavities in the sphalerite. Rosettes of barite are commonly intergrown with granular sphalerite, which may also be present as dendrites. In some places, there has been small-scale replacement of barite by sphalerite. Sphalerite contains most of the other sulfides encountered as inclusions or as cavity fill. Dendritic sphalerite contains predominantly pyrite inclusions, whereas granular sphalerite contains mostly chalcopyrite and tennantite inclusions.

Chalcopyrite forms fine (1-5 $\mu \mathrm{m}$ thick) "ribbons" outlining growth zones in sphalerite aggregates. Such zones are also outlined in places by tennantite and $\mathrm{a} \mathrm{Pb}-$ As sulfosalt with the composition of dufrénoysite $\left(\mathrm{Pb}_{2} \mathrm{As}_{2} \mathrm{~S}_{5}\right)$. Euhedral to subhedral grains of tennantite are associated with sphalerite, commonly forming a cavity-lining on sphalerite aggregates, and in some places replacing sphalerite inward from the cavities (Fig. 7a). Euhedral, triangular-shaped grains of tennantite up to $40 \mu \mathrm{m}$ in diameter occur as inclusions in sphalerite. 

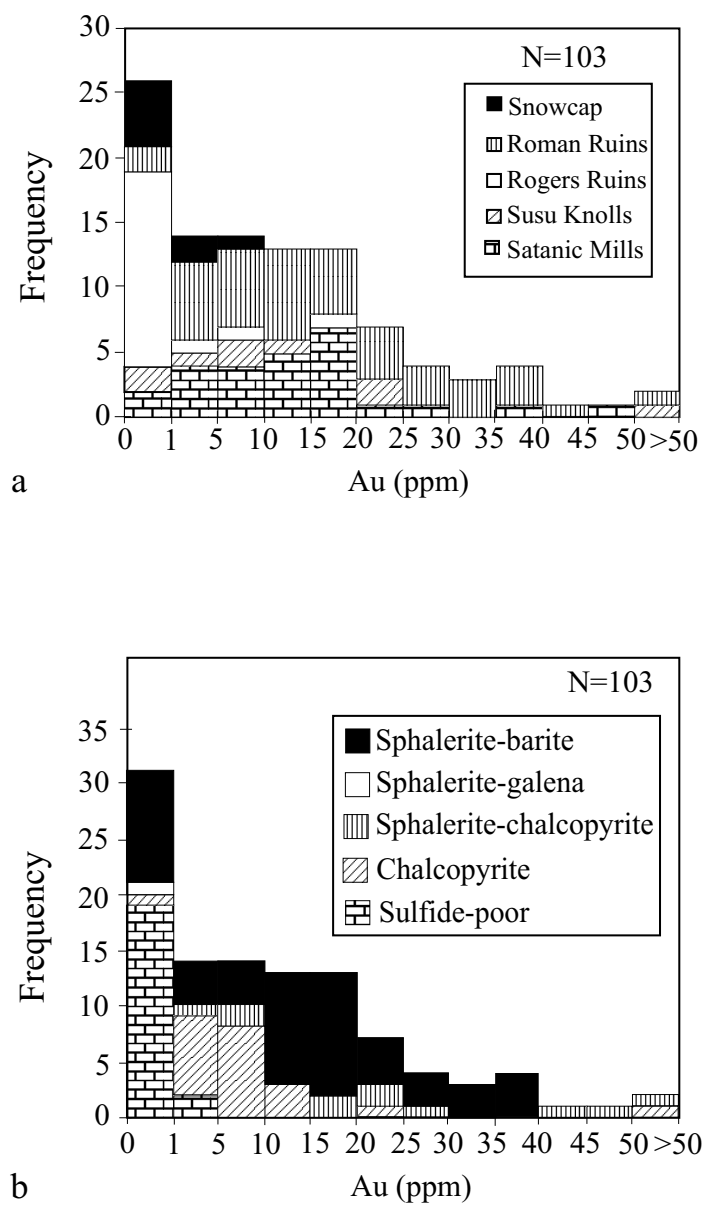

FIG. 3. Frequency distributions of gold content of hydrothermal precipitates. a. Distribution arranged by vent site. $b$. Distribution arranged by mineralogical composition of the precipitates. See text for description of mineralogical types.

Dufrénoysite is found predominantly as micrometric disseminations within sphalerite (Fig. 7b).

Spheroidal grains of pyrite up to $50 \mu \mathrm{m}$ across or aggregates of spheroidal pyrite are associated with dendritic sphalerite. In some cases, marcasite replaces pyrite, as grains radially oriented toward the core of the spheroidal pyrite. Rare bornite and covellite are associated with chalcopyrite in the chimney interior.

\section{$($ Sphalerite + galena $)$-enriched samples}

This mineralogical type is represented by only two samples, recovered from the Snowcap and Roman Ruins vent sites at PACMANUS. Sphalerite occurs both as dendritic aggregates and as porous granular aggregates that appear to have formed by continuous precipi- tation on this dendritic framework. Galena is present as subhedral to anhedral grains of $10-50 \mu \mathrm{m}$ diameter that rim and replace sphalerite, and as minor dendritic grains generally interstitial to sphalerite. Chalcopyrite, dufrénoysite, and tennantite occur as fine-grained (1-5 $\mu \mathrm{m})$ inclusions in sphalerite. Tennantite may replace galena in places (Fig. 7c). Rare grains of pyrite are interstitial to sphalerite.

\section{(Sphalerite + chalcopyrite)-rich samples}

Mineralogically zoned chimneys, typically with a chalcopyrite-rich interior and sphalerite-rich exterior, comprise this type of sample. Chalcopyrite in the chimney interior occurs as both dendritic grains and massive aggregates that are porous in places. Exsolution lamellae of chalcopyrite, showing a typical basket-weave texture, occur in bornite in some samples (Fig. 7d). Later chalcopyrite replaces this bornite-chalcopyrite assemblage in places. Covellite is always associated with bornite, generally forming a rim around bornite grains, and replacing bornite along fractures and grain boundaries. Sphalerite lines cavities in the chalcopyrite and forms a thin $(1-5 \mu \mathrm{m})$ rim around chalcopyrite aggregates. In some places, sphalerite also occurs as ribbonlike aggregates in chalcopyrite outlining growth zones or grain boundaries. Marcasite is common in chalcopyrite-rich zones, and occurs together with pyrite as very fine-grained intergrowths rimmed by chalcopyrite, and as grains and granular aggregates included in, and locally replaced by, chalcopyrite. Pyrite also occurs within chalcopyrite as euhedral to subhedral inclusions and interstitial grains. Minor barite may also occur in chimney interiors as large (up to $0.5 \mathrm{~mm}$ ) bladed grains in the cavities of chalcopyrite aggregates.

The mineralogy in the middle to outer chimney wall is dominated by massive aggregates of sphalerite that are commonly colloform and banded. The growth zones are outlined by tennantite, dufrénoysite and, more rarely, chalcopyrite. The sphalerite typically becomes more dendritic toward the outer wall of the chimneys. Chalcopyrite occurs as inclusions in sphalerite, or lines cavities in sphalerite aggregates. Tennantite and a later generation of sphalerite commonly form rims on this chalcopyrite which, in some places, replaces the earlier sphalerite. Rosettes of barite are found only in the outer portions of chimneys, typically concentrated right at the exterior wall.

\section{Chalcopyrite-rich samples}

Although some samples from the Satanic Mills vent site are chalcopyrite-rich, most samples of this type come from the Suzette vent site in the Susu Knolls area. Massive aggregates of chalcopyrite dominate, and commonly have a thin $(20 \mu \mathrm{m})$ rim of sphalerite, which also outlines grain boundaries within the chalcopyrite. Isolated grains of chalcopyrite (up to $20 \mu \mathrm{m}$ ) occur around 


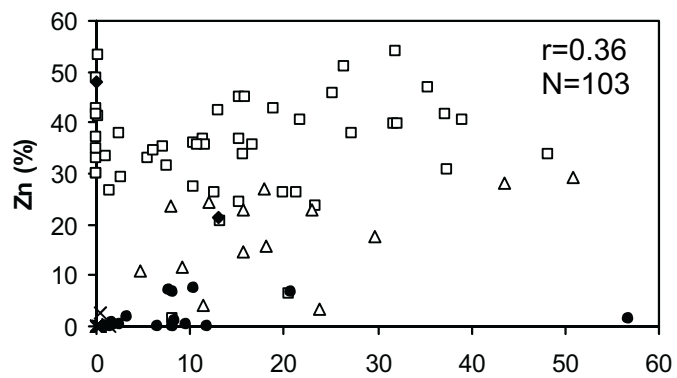

a

$\mathrm{Au}(\mathrm{ppm})$

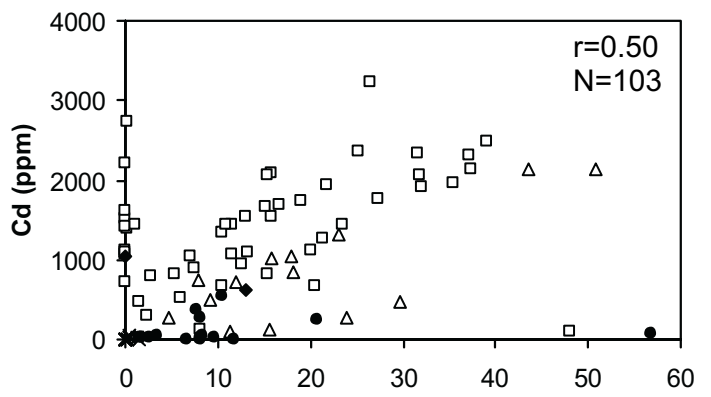

C
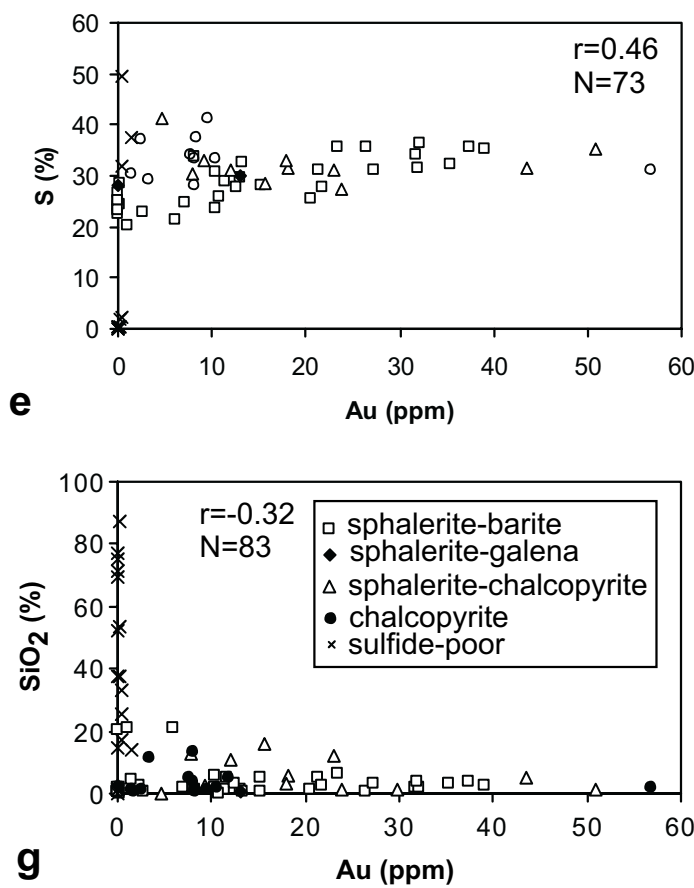
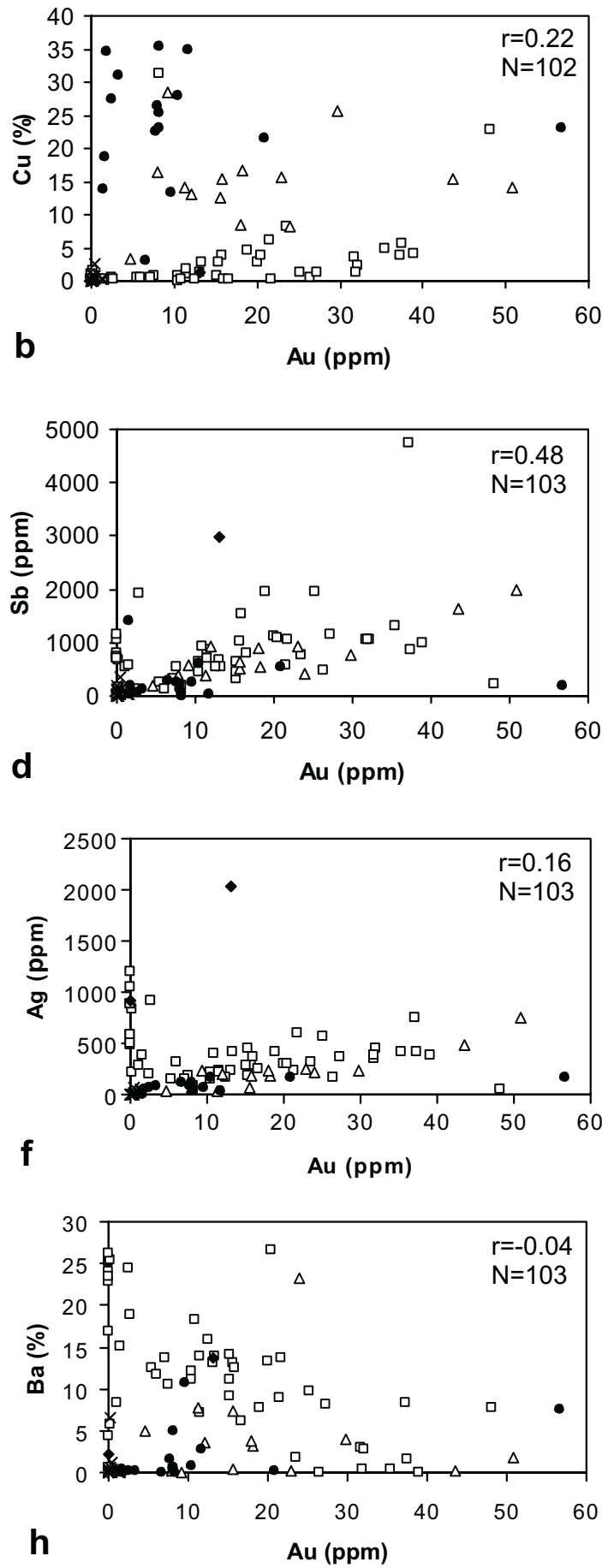

FIG. 4. Scatterplots of gold versus a) $\mathrm{Zn}$, b) $\mathrm{Cu}$, c) $\mathrm{Cd}$, d) $\mathrm{Sb}$, e) $\mathrm{S}, \mathrm{f}) \mathrm{Ag}$, g) $\mathrm{SiO}_{2}, \mathrm{~h}$ ) $\mathrm{Ba}$. 


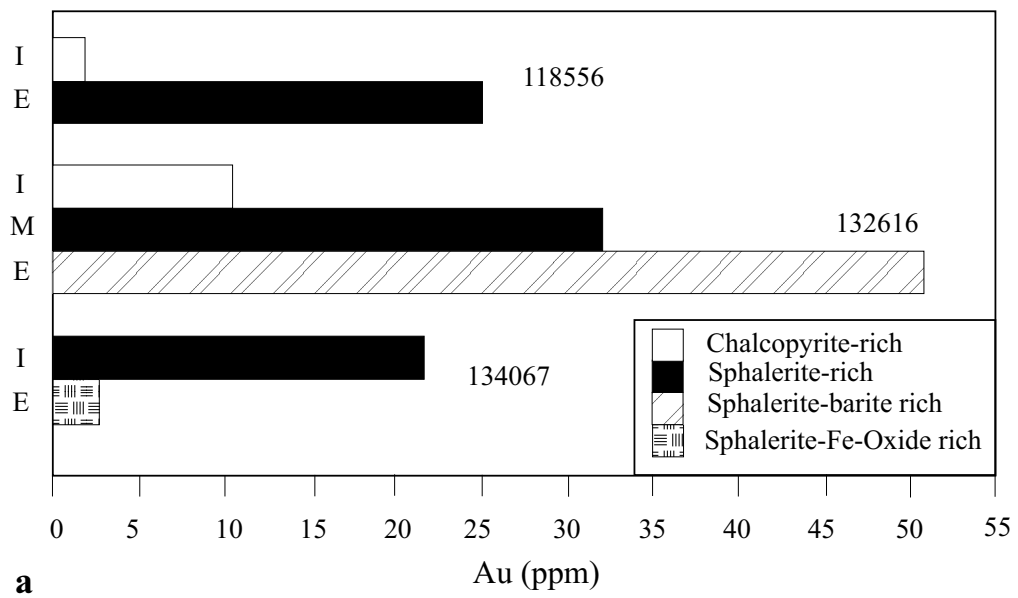

a

$\mathrm{Au}(\mathrm{ppm})$

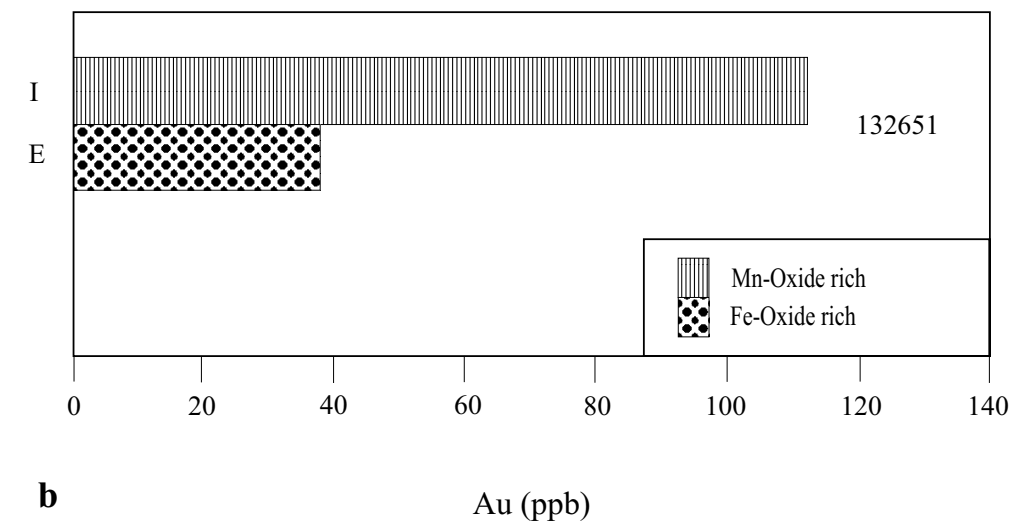

FIG. 5. Gold content of selected zoned chimneys from the PACMANUS vent field. a. Sulfide-rich chimneys. b. Oxide-rich chimneys. Note change of units (to ppb) in $b$. Numbers to the right of the bars are sample numbers. Abbreviations: I interior, M middle, E exterior chimney wall.

sphalerite rims in places, suggesting rapidly changing conditions in the fluid, with alternating precipitation of chalcopyrite and sphalerite. Tennantite is associated with the chalcopyrite-sphalerite assemblage as rare grains that separate chalcopyrite and sphalerite. Marcasite and pyrite are also associated with the massive chalcopyrite, mostly as pyrite-marcasite aggregates in which pyrite has been variably replaced by marcasite. Bornite fills cracks in the chalcopyrite aggregates, and may replace chalcopyrite inward from grain boundaries and cavities (Fig. 7e). Covellite replaces bornite along fractures in places (Fig. 7f), but also occurs as euhedral grains rimming chalcopyrite. The exterior walls of copper-rich chimneys contain minor barite, iron oxides and, rarely, atacamite $\left[\mathrm{Cu}_{2} \mathrm{Cl}(\mathrm{OH})_{3}\right]$.

\section{Sulfide-poor samples}

Sulfide-poor samples from the eastern Manus Basin fall into three groups: 1) iron-manganese oxides predominantly composed of goethite, ferrihydrite, hematite and Mn-oxide hydrate $\left.\left(\mathrm{Mn}_{7} \mathrm{O}_{13} \cdot 5 \mathrm{H}_{2} \mathrm{O}\right), 2\right)$ sulfate-rich samples dominated by barite or, more rarely, anhydrite, with lesser gypsum, and 3) silicate-rich samples that are composed mostly of amorphous silica and rare kaolinite.

\section{Occurrences of gold in sulfides at Manus}

A total of 303 grains of native gold were observed in four samples of hydrothermal precipitates from Eastern 

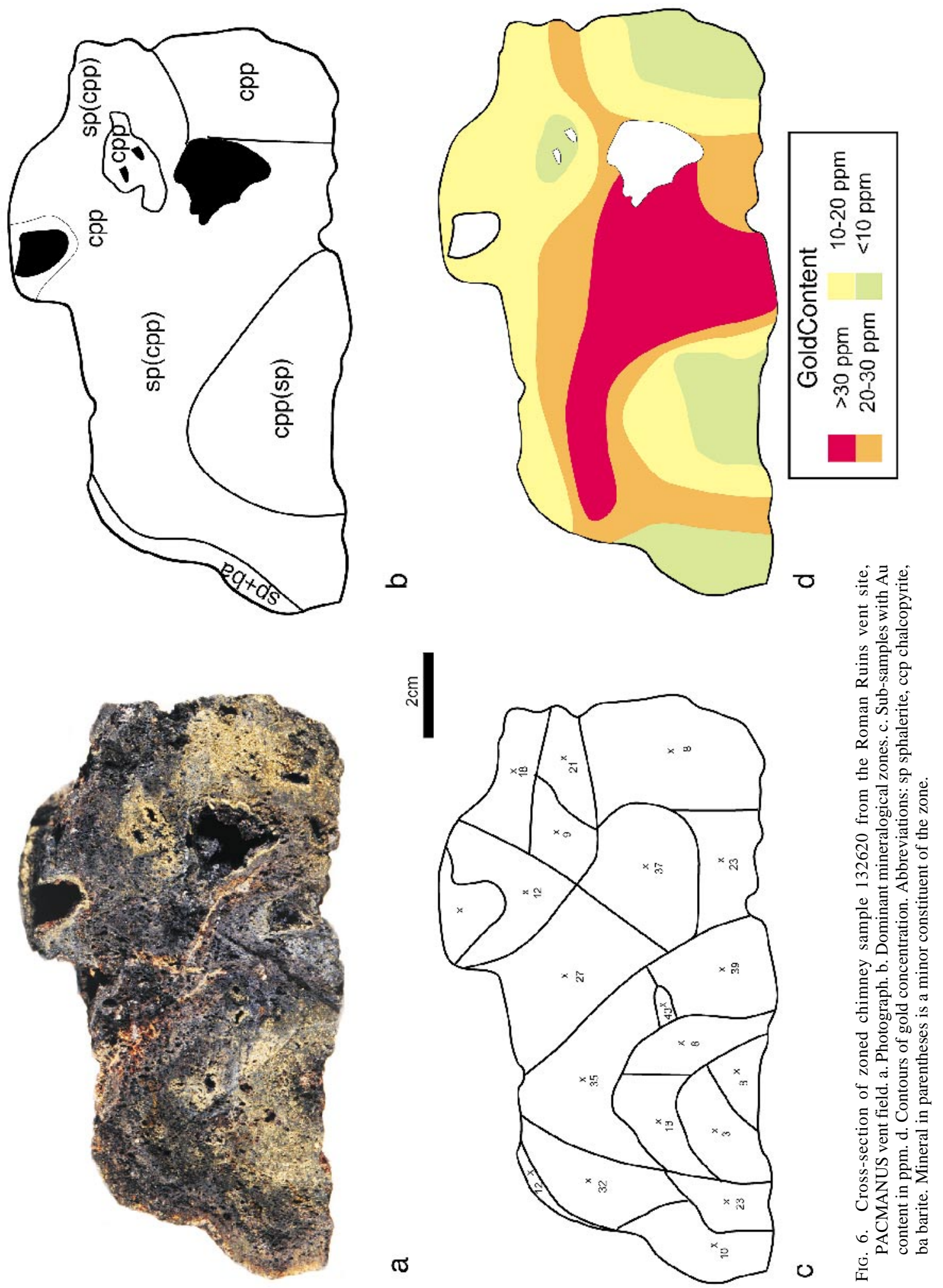

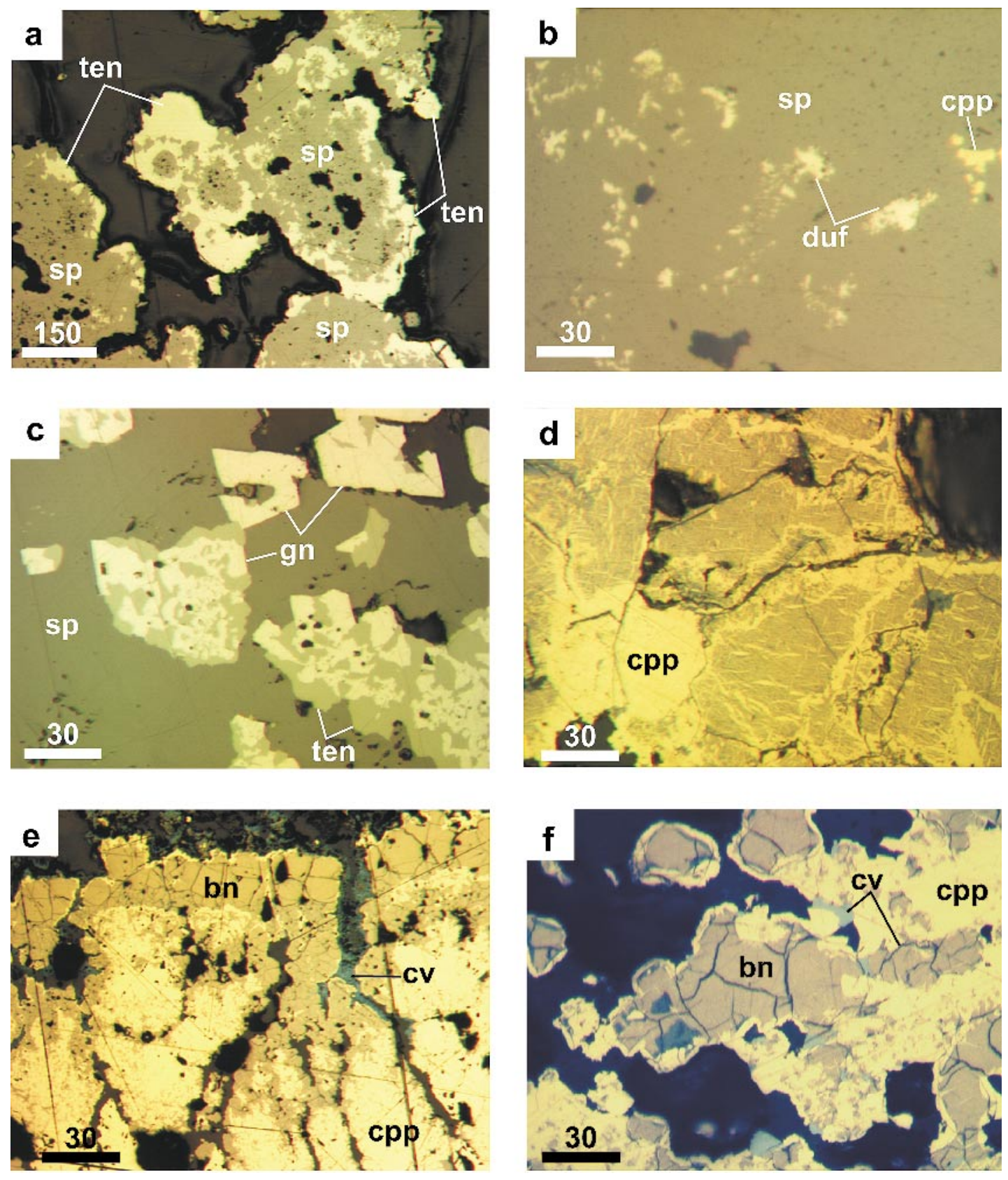

FIG. 7. Reflected-light photomicrographs of hydrothermal precipitates from the eastern Manus Basin. a. Sphalerite + barite sample. Tennantite (ten) rims massive sphalerite (sp). b. Sphalerite + barite sample. Dufrénoysite inclusions (duf) in massive sphalerite (sp). c. Sphalerite + galena \pm barite sample. Replacement of galena (gn) by tennantite (ten) in massive sphalerite (sp). d. Sphalerite - chalcopyrite sample. Exsolution lamellae of chalcopyrite (ccp) in bornite and replacement of this assemblage by chalcopyrite. e. Chalcopyrite-rich sample. Replacement of chalcopyrite (cpp) by bornite (bn) inward from a cavity located at the top of the photo. Bornite is replaced along grain boundaries by covellite (cv). f. Chalcopyrite-rich sample. Replacement of bornite (bn) by covellite (cv) along fractures and grain boundaries. Chalcopyite (cpp) rims bornite grains and lines cavities in the bornite. It also replaces bornite inward from cavities. Scales are in micrometers. 


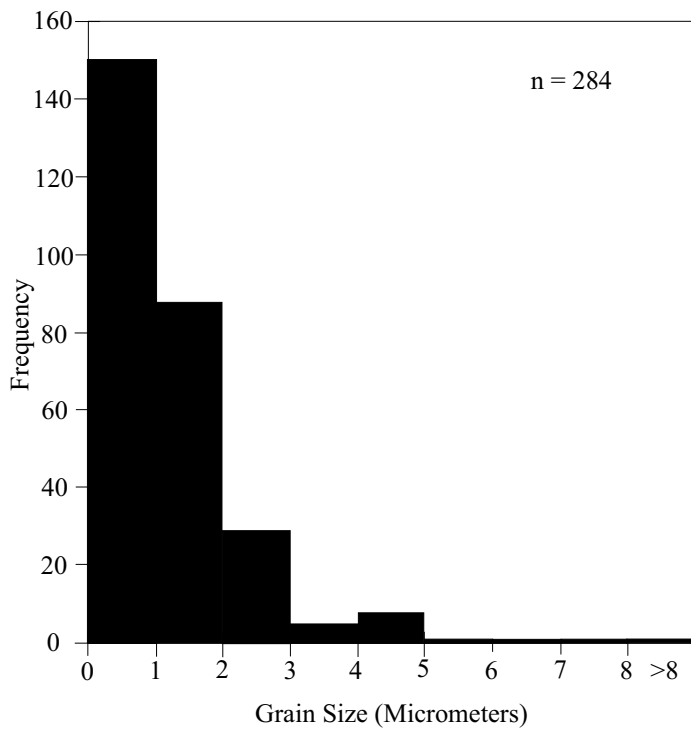

FIG. 8. Grain-size distribution of grains of native gold in sulfide chimneys from the PACMANUS and Susu Knolls vent sites.

Manus Basin. The grains are typically roundish and small; $75 \%$ of the grains are less than $3 \mu \mathrm{m}$ in diameter (Fig. 8). The main occurrence of gold grains is as inclusions in tennantite (77\% of grains found), followed by inclusions in chalcopyrite $(16 \%)$. The remainder occur as inclusions in sphalerite or bornite, fracture fill in various sulfides, and are found as isolated grains along grain boundaries and in cavities (Table 3).

Gold grains were found in a (sphalerite + barite)rich sample, two (sphalerite + chalcopyrite)-rich samples and in a chalcopyrite-rich sample. In the (sphalerite + barite)-rich sample, the grains are associated with a chalcopyrite - sphalerite - tennantite assemblage and occur mostly as inclusions in tennantite or chalcopyrite aggregates (Fig. 9a). Gold grains in chalcopyrite tend to occur close to grain boundaries with tennantite. Inclusions of tennantite also occur in sphalerite, but these inclusions do not contain grains of gold. Gold therefore occupies a very specific position in the mineral paragenesis, occurring as part of late-stage cavity-filling episodes, together with tennantite and sphalerite that lines the walls of cavities in chalcopyrite (Fig. 9b). All of the gold in this assemblage was precipitated prior to sphalerite, however, as no gold grains are visible in the sphalerite, nor in the tennantite inclusions in sphalerite.

Gold grains in chalcopyrite-rich sample 133012 from the Suzette vent site are mostly present as inclusions in chalcopyrite (Fig. 9c). Although bornite and rare covellite also form part of this assemblage, primarily replacing chalcopyrite, only one grain of gold was found associated with bornite (Table 3). The association of gold primarily with chalcopyrite indicates that it formed prior to replacement of chalcopyrite by bornite and covellite.

The interior chimney wall of zoned (sphalerite + chalcopyrite)-rich sample 132376 contains grains of gold associated with a bornite - chalcopyrite - tennantite assemblage (Fig. 9d). Gold occurs mainly as inclusions in, or as grains interstitial to, tennantite and chalcopyrite that is later than the bornite - chalcopyrite - covellite assemblage.

All of the grains of gold are silver-poor. Electronmicroprobe analyses of several grains from samples 118554-6 [(sphalerite + barite)-rich] and 132376 (chalcopyrite-rich) average $4 \pm 0.15 \mathrm{wt} . \%$ and $1.9 \pm 0.3 \mathrm{wt} . \%$ $\mathrm{Ag}$, respectively (Table 4). Gold grains of similar low content of $\mathrm{Ag}$ are associated with $\mathrm{Fe}$-poor sphalerite in sulfides in the Lau Basin (Herzig et al. 1993). Although there is a slight decrease in silver content of gold in the $\mathrm{Cu}$-rich samples over that in the $\mathrm{Zn}$-rich samples, this is very much less than that observed by Huston et al. (1992) for gold in Australian volcanogenic massive sulfide deposits.

TABLE 3. MODE OF OCCURRENCE OF GOLD GRAINS IN MANUS BASIN SULFIDES

$\begin{array}{lr}\text { Inclusions in chalcopyrite } & 49 \\ & \text { tennantite } \\ \text { sphalerite } & 232 \\ \text { bornite } & 5 \\ \text { Fractures in minerals } & 1 \\ \text { Grain boundaries } & 5 \\ \text { Cavity fill } & 7 \\ \text { Total } & 4 \\ \end{array}$

TABLE 4. COMPOSITION OF GOLD GRATNS IN EASTERN MANUS BASIN SULFIDES

\begin{tabular}{lrrrr}
\hline Sample No. & $\begin{array}{c}\text { Au } \\
\text { wt.\% }\end{array}$ & $\begin{array}{c}\text { Ag } \\
\text { wt.\% }\end{array}$ & Total & $\begin{array}{c}\text { Fine- } \\
\text { ness }\end{array}$ \\
\hline $118554-6-3$ & 101.20 & 4.24 & 105.44 & 960 \\
$118554-6-6$ & 100.20 & 3.88 & 104.08 & 963 \\
$118554-6-8$ & 98.73 & 3.97 & 102.70 & 961 \\
$118554-6-11$ & 95.05 & 4.04 & 99.09 & 959 \\
$132376-3-6$ & 102.33 & 1.58 & 103.91 & 985 \\
$132376-3-7$ & 90.49 & 2.06 & 92.55 & 978 \\
$132376-3-8$ & 99.16 & 2.06 & 101.22 & 980 \\
$132376-3-9$ & 98.54 & 1.39 & 99.93 & 986 \\
$132376-3-10$ & 101.68 & 2.00 & 103.68 & 981 \\
$132376-3-11$ & 104.73 & 1.92 & 106.65 & 982 \\
$132376-3-11(2)$ & 101.56 & 1.56 & 103.12 & 985 \\
$132376-3-12$ & 101.60 & 2.49 & 104.09 & 976 \\
$132376-3-13$ & 91.49 & 1.80 & 93.29 & 981 \\
$132376-3-14$ & 102.25 & 1.96 & 104.21 & 981 \\
& & & & \\
\hline
\end{tabular}

${ }^{1}$ High totals are a result of the difficulty in analyzing the very small grains of gold, $98 \%$ of which are less than $5 \mu \mathrm{m}$ in diameter. The small grain-size results in fluorescence of the surrounding material (typically chalcopyrite or tennantite), despite using low beam-currents. ${ }^{2}$ Fineness $=1000 \mathrm{Au} /(\mathrm{Au}+\mathrm{Ag})$ 

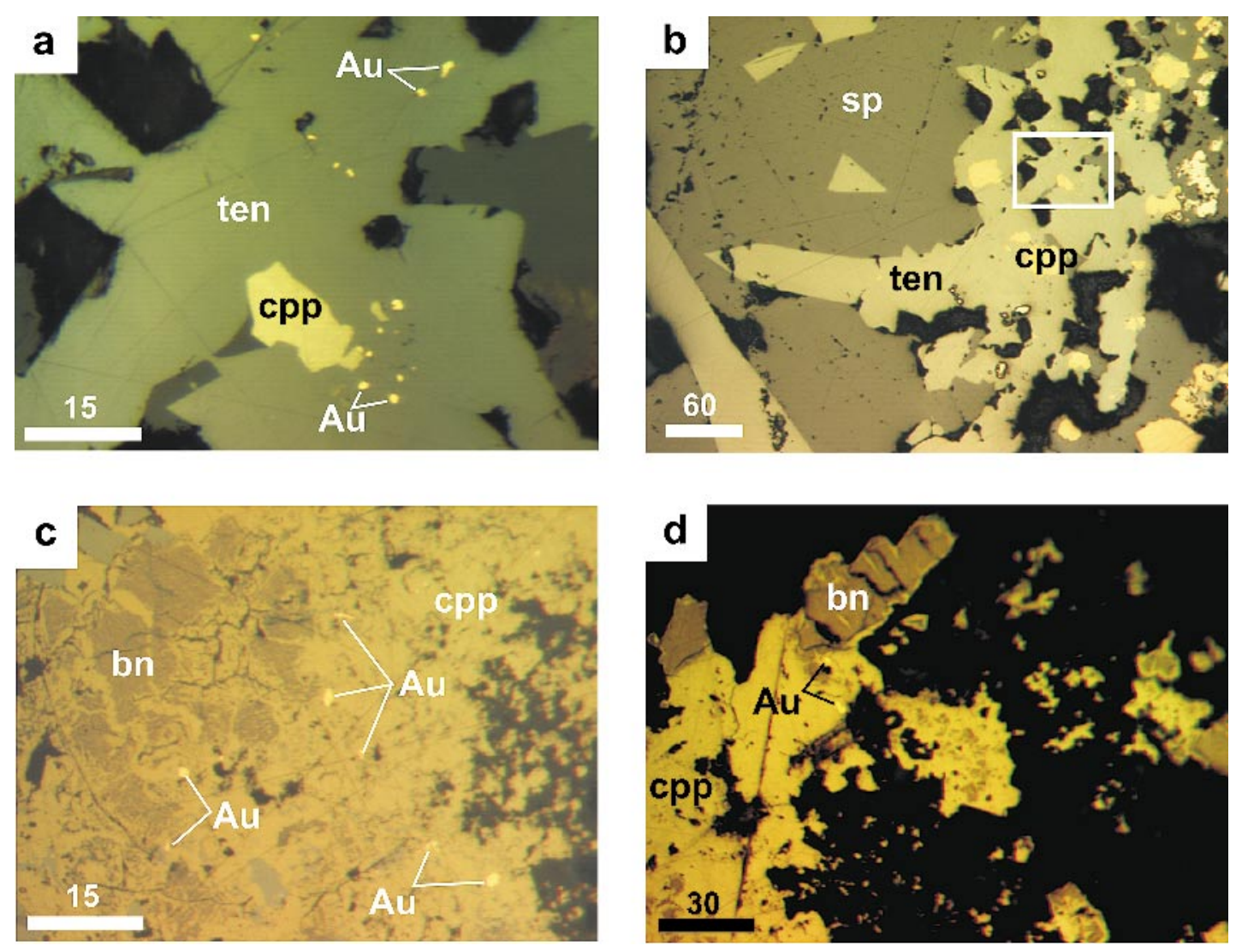

FIG. 9. Photomicrographs of native gold and associated assemblages. a. (Sphalerite + barite)-rich sample. Several inclusions of native gold $(\mathrm{Au})$ in tennantite (ten) are associated with sphalerite ( $\mathrm{sp}$ ) in a cavity lining. b. Gold - tennantite - chalcopyrite sphalerite association. Box indicates position of photomicrograph in a. The native gold occurs mainly in the tennantite (ten) that forms a rim on the chalcopyrite (cpp), but a few grains also are present in the chalcopyrite. Triangular inclusions of tennantite in sphalerite (sp) do not contain visible grains of gold. c. Zoned sphalerite-chalcopyrite-rich sample. Gold chalcopyrite - bornite association. Gold ( $\mathrm{Au}$ ) occurs mainly in the massive chalcopyrite (cpp) aggregates, and only rarely as inclusions in bornite (bn). d. Chalcopyrite-rich sample. Gold is typically associated with chalcopyrite (cpp), which is later than the chalcopyrite-bornite exsolution assemblage. Scales are in micrometers.

Gold is known to occur as submicroscopic grains, so-called "invisible" gold (Cook \& Chryssoulis 1990). This may be structurally bound gold in common sulfides such as pyrite and chalcopyrite, fine-grained gold adsorbed onto mineral surfaces, or very fine-grained (colloidal) gold in sulfide grains. The presence of such submicroscopic gold in the PACMANUS sulfides would explain the absence of grains of native gold from some samples having high bulk-gold contents, as suggested by Hannington et al. (1995) for gold in the TAG precipitates. The significant positive correlation of gold with $\mathrm{Zn}, \mathrm{Cd}$, and $\mathrm{S}$ in the PACMANUS sulfides (Fig. 4) and the lack of such a correlation with Ag or As suggest that although the microscopically visible gold occurs in association with tennantite and chalcopyrite, a signifi- cant proportion of the gold at PACMANUS is present as "invisible" gold in sphalerite. Attempts to determine the amount of gold in the sphalerite by secondary-ion mass spectroscopy were unsuccessful owing to the very fine-grained nature of the sphalerite.

\section{DISCUSSION}

\section{Mineralogical associations of native gold}

There are three mineralogical associations of gold in eastern Manus Basin sulfides: a chalcopyrite sphalerite - tennantite association, a chalcopyrite bornite \pm covellite association and a chalcopyrite tennantite \pm bornite - covellite association. Native gold 
occurs predominantly as micrometric inclusions in tennantite and chalcopyrite. The chalcopyrite - sphalerite - tennantite association is present in the (sphalerite + barite)-rich chimneys. Similar occurrences of native gold have been described from other seafloor vent-sites (e.g., Hannington \& Scott 1989a, b, Herzig et al. 1993), but in most of these cases the host is Fe-poor sphalerite with associated tetrahedrite or tennantite. Native gold and a gold-silver alloy ("electrum") have also been reported from zinc-rich assemblages in ancient deposits. Australian volcanogenic massive sulfide deposits of the $\mathrm{Zn}-\mathrm{Pb}-\mathrm{Ag}-\mathrm{Au}$ type typically contain "electrum" associated with galena, sphalerite, chalcopyrite and tetrahedrite-tennantite (Huston et al. 1992), as do deposits of the Rio Tinto - Aznalcollar-La Zarza type of the Iberian Pyrite Belt (Leistel et al. 1998). The association of native gold with low-temperature $\left(<300^{\circ} \mathrm{C}\right) \mathrm{Zn}$-rich precipitates is commonly believed to be due to the transport of gold predominantly as the $\mathrm{Au}(\mathrm{HS})_{2}{ }^{-}$complex (e.g., Hannington \& Scott 1989a, b, Huston \& Large 1989).

Gold-copper associations, such as the gold - chalcopyrite - bornite \pm covellite assemblage found in copper-rich chimneys at Suzette, are rare in seafloor sulfide deposits. Gossans developed on the TAG and MIR hydrothermal mounds on the Mid-Atlantic Ridge have an average gold content of $11.4 \mathrm{ppm}$ and contain abundant grains of native gold associated with covellite, digenite, native copper and atacamite (Hannington et al. 1988). However, these copper minerals at TAG are secondary, resulting from oxidation processes on the seafloor (Hannington et al. 1988, Herzig et al. 1993), and are not comparable to the primary association found in eastern Manus Basin. A gold-copper association occurs in the ultramafic-rock-hosted Logatchev hydrothermal field at $14^{\circ} 45^{\prime} \mathrm{N}$ on the Mid-Atlantic Ridge (Murphy \& Meyer 1998). Here, gold mineralization is found both as primary grains of native gold included in chalcopyrite associated with sphalerite and isocubanite, and as secondary gold associated with a chalcopyrite - bornite - covellite assemblage. Occurrences of gold-copper associations have been well documented in ancient volcanogenic massive sulfide deposits (Huston \& Large 1989, Large 1990, Huston et al. 1992, Leistel et al. 1998). Such associations have been interpreted as resulting from chloride complexing of gold in high-temperature $\left(>300^{\circ} \mathrm{C}\right)$ fluids with precipitation due, in most part, to decreasing temperature (e.g., Huston \& Large 1989).

\section{Effect of sulfur activity on gold concentration}

The assemblages of sulfide minerals observed in Manus Basin, such as tennantite, chalcopyrite, bornite and pyrite, indicate a high activity of sulfur for sample types containing native gold. Also, electron-microprobe analyses of 68 sphalerite grains and aggregates from 13 PACMANUS samples have a low average iron content,
$2.3 \pm 3.1$ mole $\%$ FeS (Fig. 10a), implying a high activity of sulfur. The low silver content of the gold grains in eastern Manus Basin also indicates a high activity of sulfur. The silver content of "electrum" in equilibrium with $\mathrm{Ag}_{2} \mathrm{~S}$ (or another Ag-bearing phase) is inversely proportional to the activity of sulfur (Barton \& Toulmin 1964), as shown in equation 1.

$$
\begin{aligned}
& \mathrm{Ag}_{(\mathrm{s})}+1 / 4 \mathrm{~S}_{2(\mathrm{~g})}=1 / 2 \mathrm{Ag}_{2} \mathrm{~S}_{(\mathrm{s})} \\
& a_{\mathrm{Ag}}=a_{\mathrm{Ag} 2 \mathrm{~S}}{ }^{1 / 2} \times a_{\mathrm{S} 2}{ }^{-1 / 4} \times \mathrm{k}^{-1}
\end{aligned}
$$

The high activity of sulfur is consistent with the transport of gold as a reduced sulfur complex. There is no correlation of mole $\% \mathrm{FeS}$ in sphalerite with the bulkgold content of the PACMANUS samples (Fig. 10b), as was found to be the case with Tasmanian volcanogenic massive sulfide deposits (Zaw \& Large 1996). However, when these parameters are plotted together with results from other seafloor vent-sites, the eastern Manus Basin data lie on a trend toward higher gold values with lower iron content of sphalerite (Fig. 11).

The concentration of gold in hydrothermal precipitates has been shown to be inversely related to the FeS content of sphalerite (Hannington \& Scott 1989b). The FeS content of sphalerite coexisting with pyrite or pyrrhotite is known to be inversely related to the activity of sulfur (Barton \& Toulmin 1966, Scott \& Barnes 1971). Thus the gold content of seafloor sulfide deposits is related to the activity of sulfur, being generally highest where the activity of sulfur is highest (Hannington \& Scott $1989 b$ ). This correlation is primarily due to the transport of gold as a sulfide complex in low-temperature $\left(<300^{\circ} \mathrm{C}\right)$, reduced, sulfur-rich fluids that typically form gold-rich precipitates (Hannington \& Scott 1989b). The Cambrian massive sulfide deposits in Tasmania also show a trend of increasing gold values with decreasing mole \% FeS in sphalerite (Zaw \& Large 1996). Although the correlation within an individual deposit is poor, it improves significantly if the values for each deposit are averaged and plotted as an individual point. Several reasons are put forth by Zaw \& Large (1996) for this lack of correlation within a deposit, including later metamorphic effects, and factors other than sulfur activity and temperature controlling gold transport. Although it is clear that factors such as $\mathrm{pH}$ and oxygen activity play a role in transporting gold, inspection of relevant equations presented below indicates that the activity of reduced sulfur (in this case as $\mathrm{H}_{2} \mathrm{~S}$ ) is the most important control on gold transport as a reduced sulfur complex.

\section{Transport of gold in seafloor hydrothermal systems}

Experimental studies of gold solubility have focused mainly on the ability of chloride and reduced sulfur ligands to complex gold, owing to their availability in hydrothermal systems (Seward 1991). There is a general consensus that gold is transported as the bisulfide 

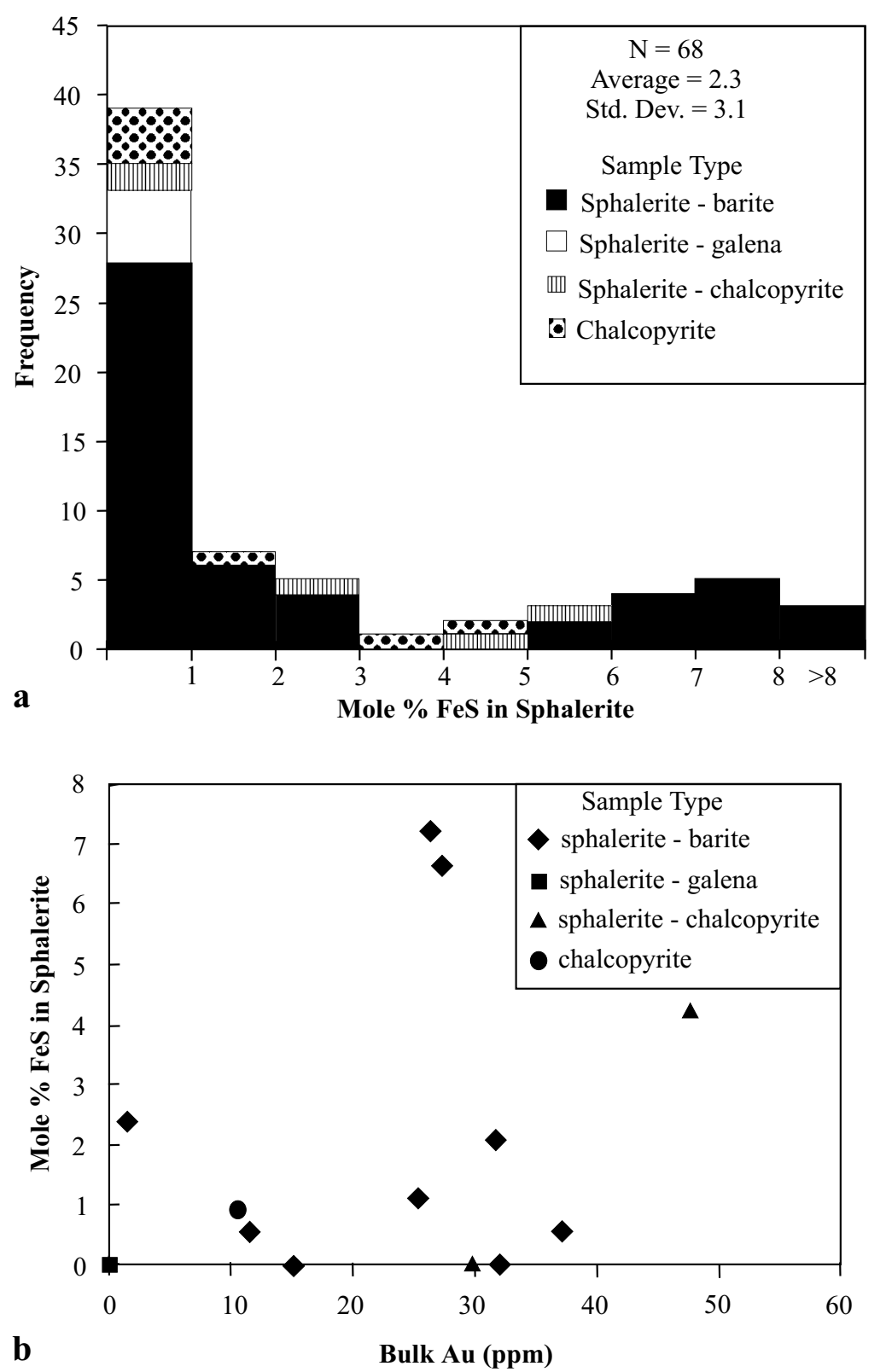

FIG. 10. a. Frequency distribution of mole $\% \mathrm{FeS}$ in sphalerite in samples from the PACMANUS and Susu Knolls vent fields. b. Plot of average mole \% FeS versus average gold content of the samples. See text for description of sample types.

$\mathrm{Au}(\mathrm{HS})_{2}{ }^{-}$complex in fluids of low salinity, near-neutral $\mathrm{pH}$, temperatures less than about $350^{\circ} \mathrm{C}$ and moderately reducing conditions (e.g., Seward \& Barnes 1997). For gold transport in fluids of low $\mathrm{pH}$, low salinity and temperatures up to $350^{\circ} \mathrm{C}$, Hayashi \& Ohmoto (1991) proposed the $\mathrm{HAu}(\mathrm{HS})_{2}{ }^{\circ}$ complex. However, recent experimental work has shown that the $\mathrm{AuHS}^{\circ}$ complex is dominant under these conditions (Benning \& Seward 1996).

Chloride complexing of gold has also been the source of some debate, as Cole \& Drummond (1986) have suggested that the stability of the $\mathrm{AuCl}_{2}^{-}$complex 


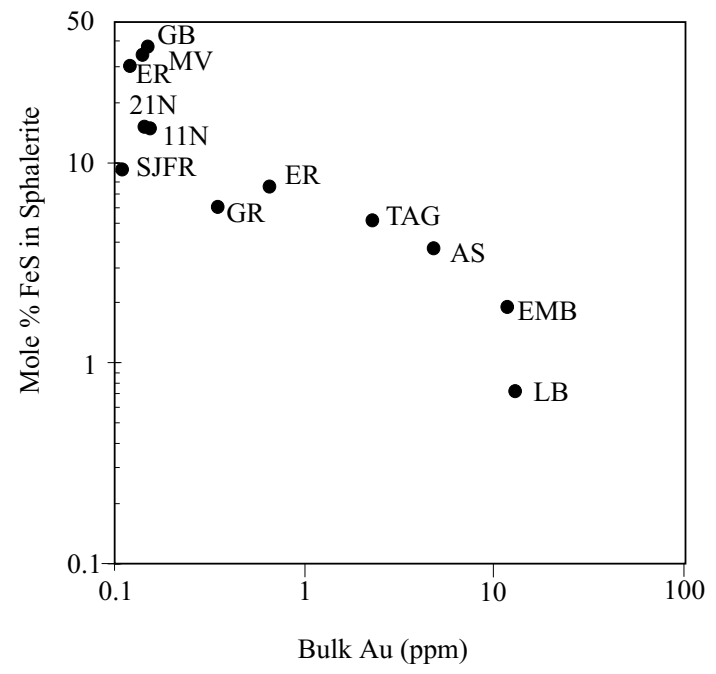

FIG. 11. Plot of average mole \% FeS versus average gold content for seafloor VMS deposits. Abbreviations: GB Guaymas Basin, MV Middle Valley, ENR Endeavour Ridge, $21 \mathrm{~N} 21^{\circ} \mathrm{N}$ East Pacific Rise, $11 \mathrm{~N} 11^{\circ} \mathrm{N}$ East Pacific Rise, SJFR Southern Juan de Fuca Ridge, GR Galapagos Ridge, ER Explorer Ridge, AS Axial Seamount, EMB eastern Manus Basin, LB Lau Basin. Sources of data: Lau Basin: Herzig et al. (1993); eastern Manus Basin: this study; all other data: Hannington \& Scott (1989b). is far greater than that predicted by Helgeson (1969). However, Seward (1991) demonstrated that the data of Helgeson comprise part of a consistent dataset over the temperature range $25^{\circ} \mathrm{C}$ to $374^{\circ} \mathrm{C}$. In addition, the experimental results of Zotov et al. (1991) and Gammons et al. (1994) have confirmed Helgeson's predicted solubilities. The solubility predicted by Sverjensky et al. (1997) and determined experimentally by Gammons \& Williams-Jones (1995) is somewhat higher (Fig. 12). Sverjensky et al. (1997) also presented data for the $\mathrm{AuCl}$ and $\mathrm{AuCl}_{3}{ }^{2-}$ complexes, which are used in this study together with the solubility for the $\mathrm{AuCl}_{2}{ }^{-}$complex predicted by Sverjensky et al. (1997) to evaluate gold transport as chloride complexes. The $\mathrm{Au}(\mathrm{OH})^{\circ}$ complex may also play a role in gold transport at temperatures between $300^{\circ}$ and $500^{\circ} \mathrm{C}$ (Gammons \& Williams-Jones 1997).

Six complexes are therefore evaluated as possible carriers of gold in the hydrothermal systems of the eastern Manus Basin. Gold transport as a reduced sulfur complex may be represented by:

$$
\begin{aligned}
& \mathrm{Au}_{(\mathrm{s})}+2 \mathrm{H}_{2} \mathrm{~S}_{(\mathrm{aq})}+1 / 4 \mathrm{O}_{2}=\mathrm{Au}(\mathrm{HS})_{2}{ }^{-} \\
& +\mathrm{H}^{+}+1 / 2 \mathrm{H}_{2} \mathrm{O}
\end{aligned}
$$

or

$$
\mathrm{Au}_{(\mathrm{s})}+\mathrm{H}_{2} \mathrm{~S}_{(\mathrm{aq})}+1 / 4 \mathrm{O}_{2}=\mathrm{AuHS}^{\circ}+1 / 2 \mathrm{H}_{2} \mathrm{O}
$$

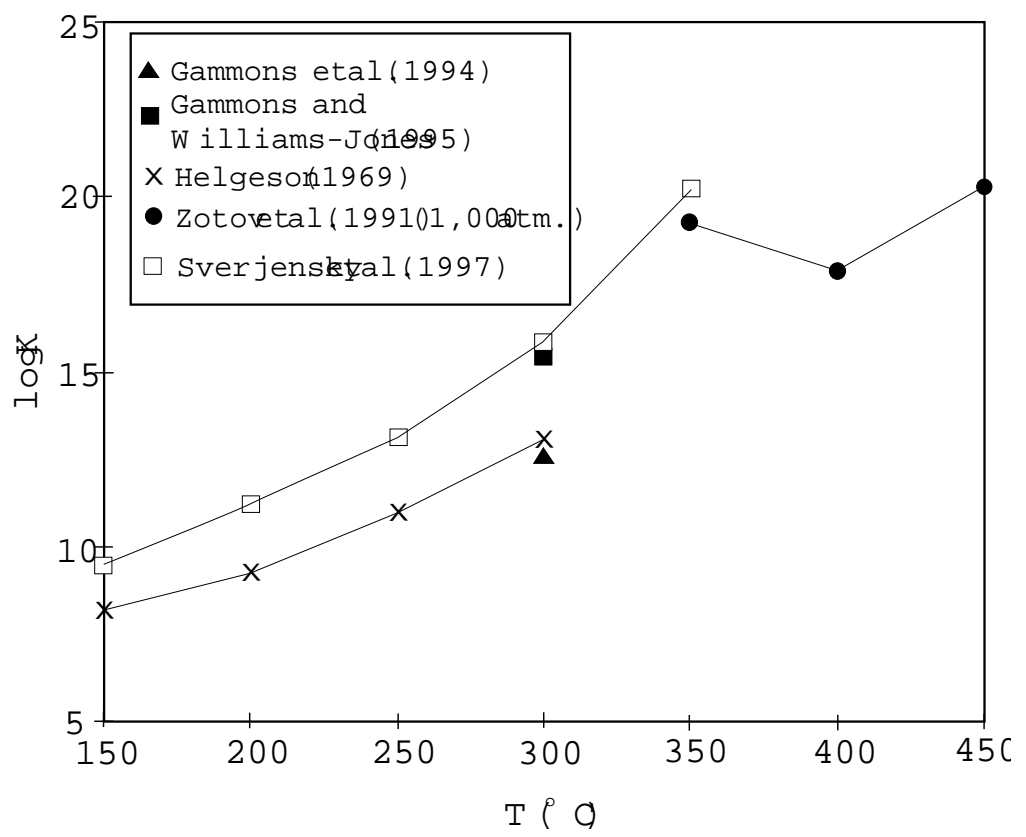

FIG. 12. Comparison of experimentally determined and calculated stabilities of the $\mathrm{AuCl}_{2}{ }^{-}$ complex (Equation 5). 
chloride complexing of gold by:

$$
\begin{aligned}
& \mathrm{Au}_{(\mathrm{s})}+\mathrm{Cl}^{-}+\mathrm{H}^{+}+1 / 4 \mathrm{O}_{2}=\mathrm{AuCl}^{\circ}+1 / 2 \mathrm{H}_{2} \mathrm{O} \\
& \mathrm{Au}_{(\mathrm{s})}+2 \mathrm{Cl}^{-}+\mathrm{H}^{+}+1 / 4 \mathrm{O}_{2}=\mathrm{AuCl}_{2}^{-}+1 / 2 \mathrm{H}_{2} \mathrm{O} \\
& \mathrm{Au}_{(\mathrm{s})}+3 \mathrm{Cl}^{-}+\mathrm{H}^{+}+1 / 4 \mathrm{O}_{2}=\mathrm{AuCl}_{3}^{2-}+1 / 2 \mathrm{H}_{2} \mathrm{O}
\end{aligned}
$$

and hydroxide complexing of gold by:

$$
\mathrm{Au}_{(\mathrm{s})}+1 / 2 \mathrm{H}_{2} \mathrm{O}+1 / 4 \mathrm{O}_{2}=\mathrm{Au}(\mathrm{OH})^{\circ}
$$

From equation 2, the solubility of gold as the $\mathrm{Au}(\mathrm{HS})_{2}{ }^{-}$ complex is primarily dependent on the activity of $\mathrm{H}_{2} \mathrm{~S}$ and $\mathrm{pH}$ and, to a lesser extent, on oxygen activity. Equation 3 indicates that the solubility of gold as the $\mathrm{AuHS}^{\circ}$ complex is also primarily dependent on the activity of $\mathrm{H}_{2} \mathrm{~S}$, but is independent of $\mathrm{pH}$ where $\mathrm{H}_{2} \mathrm{~S}$ is the stable sulfur species. From equations 4, 5 and 6 , the stability of the gold chloride complexes is primarily dependent on the activity of chloride and $\mathrm{pH}$ and, to a lesser extent, on oxygen activity. Equation 7 indicates that gold carried as the $\mathrm{Au}(\mathrm{OH})^{\circ}$ complex is predominantly dependent on oxygen activity.

The effect of $\mathrm{pH}$ on the chloride and sulfide complexes is shown for a PACMANUS-type vent fluid at $250^{\circ} \mathrm{C}$ in Figure $13 \mathrm{a}$. The $\mathrm{AuHS}^{\circ}$ complex is clearly the most stable in the acid $\mathrm{pH}$ region, but $\mathrm{Au}(\mathrm{HS})_{2}{ }^{-}$becomes the most stable complex at $\mathrm{pH}$ greater than about 4.5. The gold chloride species $\mathrm{AuCl}_{2}{ }^{-}$is more stable than the bisulfide species $\mathrm{Au}(\mathrm{HS})_{2}{ }^{-}$(but much less stable than the AuHS ${ }^{\circ}$ species) only in the very acid regions up to a $\mathrm{pH}$ of approximately 2 . Thereafter, the bisulfide complex rapidly becomes the more stable of the two.

Temperature is also a key control on the complexing of gold, and is evaluated, for the PACMANUS-type fluid, at $\mathrm{pH}=3$, in Figure 13b. The sulfide complexes are clearly more stable than the chloride complexes up to close to $300^{\circ} \mathrm{C}$, at which point the $\mathrm{AuCl}_{2}{ }^{-}$species becomes more stable than the $\mathrm{Au}(\mathrm{HS})_{2}{ }^{-}$species. However, even at this temperature, the concentration of the $\mathrm{AuHS}^{\circ}$ species is two orders of magnitude greater than the chloride complex. Therefore, the bisulfide complex $\mathrm{Au}(\mathrm{HS})_{2}{ }^{-}$is the most stable of the three complexes up to about $140^{\circ} \mathrm{C}$, after which $\mathrm{AuHS}^{\circ}$ becomes the stable complex up to $325^{\circ} \mathrm{C}$. Calculations of gold solubility in the temperature range $300^{\circ}$ to $400^{\circ} \mathrm{C}$ at $1 \mathrm{kbar}$ indicate that the AuHS ${ }^{\circ}$ complex remains the most stable of the complexes to a temperature of about $322^{\circ} \mathrm{C}$. At this temperature, the neutral $\mathrm{Au}(\mathrm{OH})^{\circ}$ complex becomes the most stable, and continues to be the dominant complex beyond $400^{\circ} \mathrm{C}$ (Fig. 13c).

The availability of suitable ligands to complex the gold plays a significant role in the transport of gold. A predominance-area diagram illustrating the fields of the complexes as a function of chloride and $\mathrm{H}_{2} \mathrm{~S}$ activity is shown in Figure 14. At very high activities of $\mathrm{H}_{2} \mathrm{~S}$, the
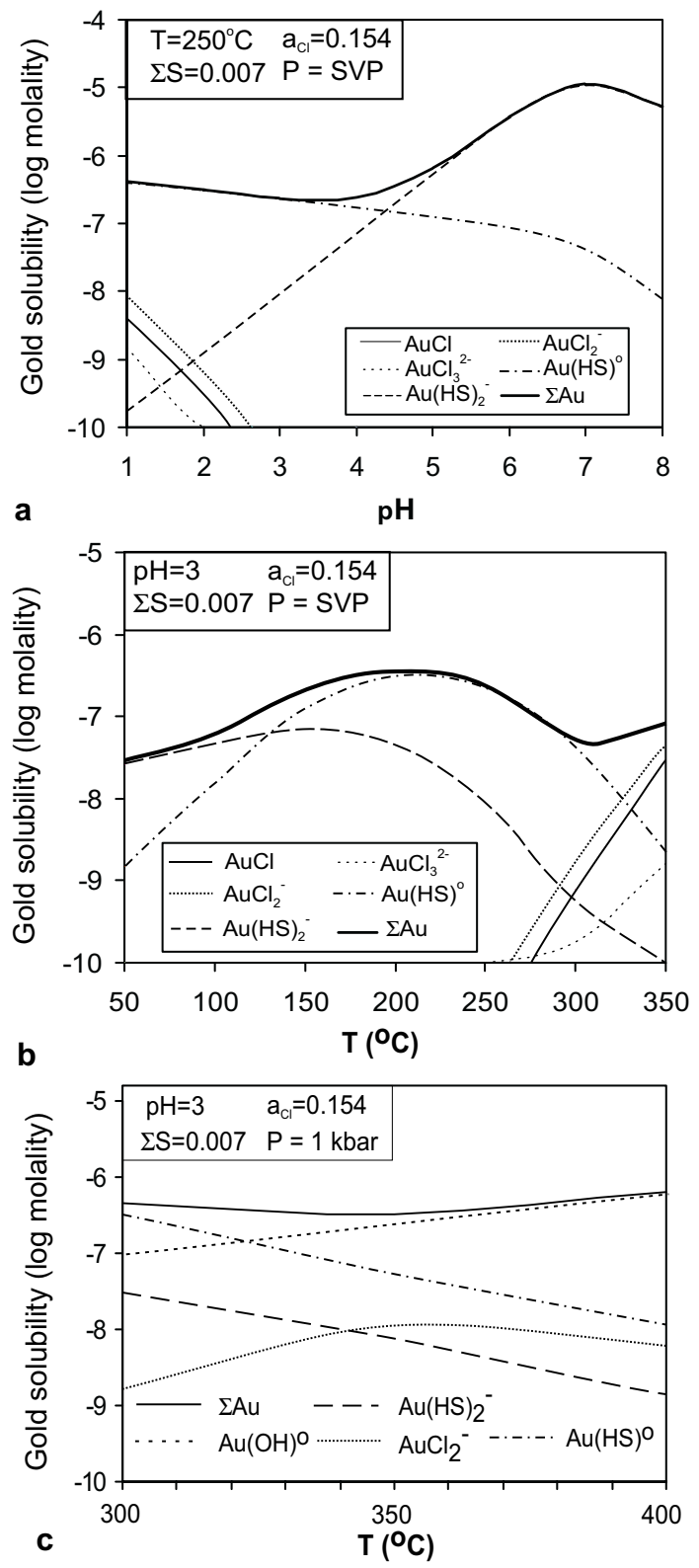

FIG. 13. Solubility of gold in a PACMANUS-like fluid a) as a function of $\mathrm{pH}, \mathrm{b}$ ) as a function of temperature, and c) for $\mathrm{T}$ between 300 and $400^{\circ} \mathrm{C}$ and $\mathrm{P}=1 \mathrm{kbar}$. Gold acetate complexes have solubilities of $<-10$ log molal. Fluid composition is based on analyses of PACMANUS vent fluids (T. Gamo, pers. commun., 1995) extrapolated to $0 \mathrm{Mg}$, with activity of species and high-temperature $\mathrm{pH}$ calculated using SOLMINEQ.88 (Kharaka et al. 1988). Solubility was calculated using the EQBRM code (Anderson \& Crerar 1993) with thermodynamic data from Benning \& Seward (1996), Sverjensky et al. (1997), Suleimenov \& Seward (1997), Johnson et al. (1992), and Zotov et al. (1985, 1991). SVP: saturated vapor pressure. 
$\mathrm{Au}(\mathrm{HS})_{2}{ }^{-}$complex is favored, and gold solubility can reach very high values. At lower activities of $\mathrm{H}_{2} \mathrm{~S}$ and low activity of chloride, gold is transported predominantly as the $\mathrm{AuHS}^{\circ}$ complex, with a maximum solubility of $1.2 \mathrm{ppm} \mathrm{Au}$. At sufficiently low values of $\mathrm{H}_{2} \mathrm{~S}$ activity and relatively high chloride activity, gold is transported predominantly as a chloride complex. The $\mathrm{AuCl}$ complex is only important at very low activities of $\mathrm{H}_{2} \mathrm{~S}\left[\log a\left(\mathrm{H}_{2} \mathrm{~S}\right)<-6\right]$ and low chloride activity. As the chloride activity increases, $\mathrm{AuCl}_{2}{ }^{-}$becomes the predominant chloride complex, and finally at very high activity of chloride, $\mathrm{AuCl}_{3}{ }^{2-}$ is predominant. Average values of $a\left(\mathrm{H}_{2} \mathrm{~S}\right)$ and $a\left(\mathrm{Cl}^{-}\right)$for the PACMANUS vent field indicate that gold in the PACMANUS system is most likely carried as the AuHS ${ }^{\circ}$ complex, and has a maximum solubility of about $100 \mathrm{ppb}$ (Fig. 14). Of course, the actual concentration of gold in the PACMANUS end-member fluid could be less than this value indicative of saturation.

Deposition of gold carried as the AuHS ${ }^{\circ}$ complex can be caused by 1 ) a decrease in $a\left(\mathrm{H}_{2} \mathrm{~S}\right)$ (see Fig. 14), which may result from dilution by ambient seawater, precipitation of sulfides, or phase separation with loss of $\mathrm{H}_{2} \mathrm{~S}$ to the vapor phase, 2) a change in $\mathrm{pH}$ (see Fig. 13a), and 3) sufficient oxidation to convert reduced sulfide to sulfate (Fig. 15). The effects of temperature on the solubility of gold are variable. At temperatures between approximately $322^{\circ}$ and $200^{\circ} \mathrm{C}$, gold solubility actually increases as temperature decreases owing to the predominance of bisulfide complexes (Fig. 13b). At lower temperatures, gold solubility decreases with the concentration of the gold bisulfide complexes. In the case of seafloor hydrothermal systems, such as PACMANUS, precipitation of gold from the hydrothermal fluid can be accomplished efficiently by mixing with seawater (Hannington \& Scott 1989a). Such mixing causes a decrease in $a\left(\mathrm{H}_{2} \mathrm{~S}\right)$ and an increase in $\mathrm{pH}$ and $a\left(\mathrm{O}_{2}\right)$, all of which can result in precipitation of gold. Boiling may also be important in shallow submarine hydrothermal systems (Hannington et al. 1999). If boiling does occur, it will cause loss of $\mathrm{H}_{2} \mathrm{~S}$ to the gas phase prior to, or together with, mixing with seawater. This would result in more efficient precipitation of gold carried as a bisulfide complex than would mixing with seawater alone.

\section{Conclusions}

Gold-rich hydrothermal precipitates from the eastern Manus Basin are associated with both $\mathrm{Zn}$ - and $\mathrm{Cu}-$

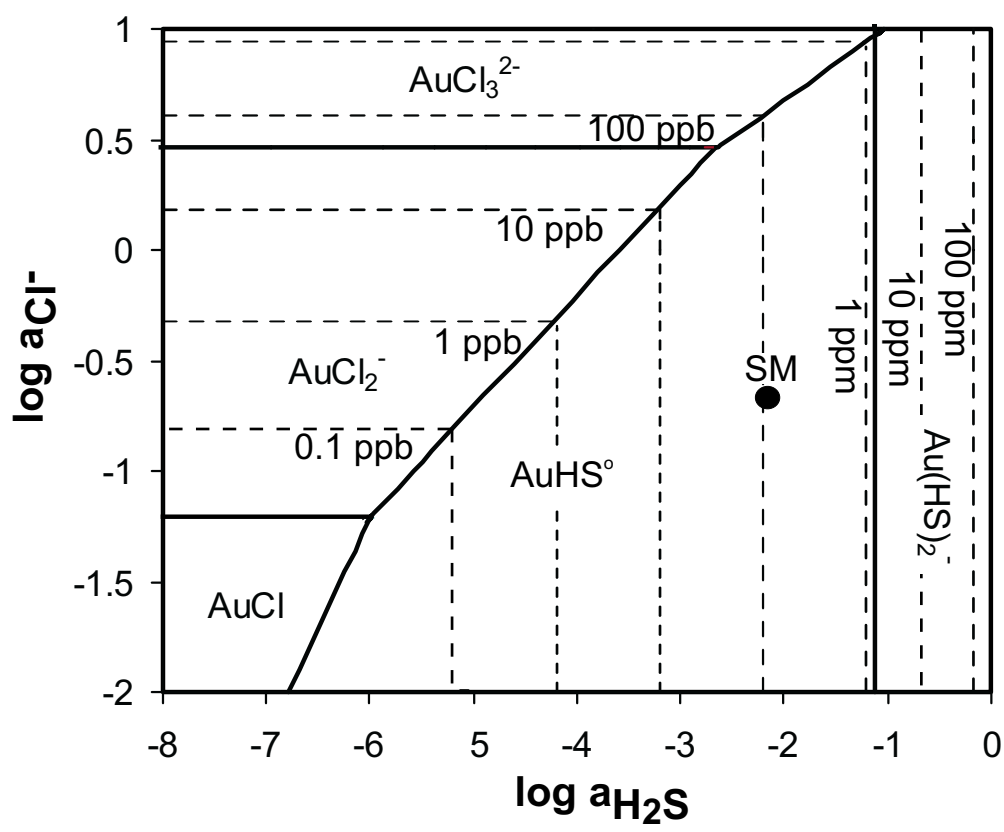

FIG. 14. Predominance-field diagram for selected complexes of gold, showing the position of the Satanic Mills $(\mathrm{SM})$ vent fluid. $\mathrm{T}=250^{\circ} \mathrm{C}, \mathrm{pH}=3, \mathrm{P}=$ saturated vapor pressure. Contours are for gold solubility in parts per billion. Oxygen fugacity is fixed by $a\left(\mathrm{H}_{2} \mathrm{~S}\right)=a\left(\mathrm{SO}_{4}\right)^{2-}$ compatible with the common occurrence of gold in sulfide-sulfate assemblages. Thermodynamic data as for Figure 13. 


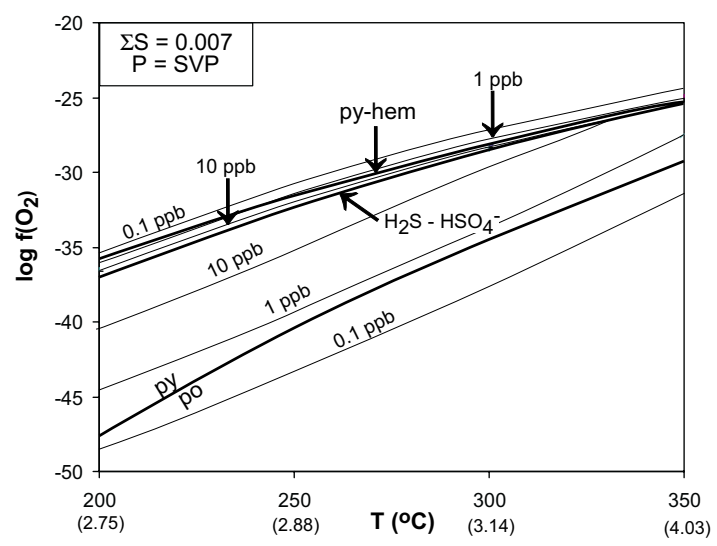

FIG. 15. Gold solubility as the AuHS ${ }^{\circ}$ complex as a function of oxygen fugacity and temperature. Also shown are boundaries for selected iron sulfide and iron oxide minerals and the sulfate-sulfide boundary (heavy lines). The $\mathrm{pH}$ is given in parentheses below each temperature and reflects the decrease in $\mathrm{pH}$ accompanying conductive cooling of the PACMANUS vent fluid. The total reduced sulfur and pressure are the same as in Figure 13, as are the thermodynamic data.

rich mineral assemblages. In Zn-rich assemblages, grains of native gold occur predominantly as inclusions in tennantite that occupies an intermediate paragenetic position between early-formed chalcopyrite and later cavity-filling sphalerite. Gold in $\mathrm{Cu}$-rich assemblages is present as micrometric grains included in massive chalcopyrite. This gold is primary, and is not the result of seafloor oxidation, as has been reported from the TAG (Hannington et al. 1988) and Logatchev (Murphy \& Meyer 1998) hydrothermal fields.

The neutral AuHS ${ }^{\circ}$ complex is considered the most important carrier of gold in the PACMANUS hydrothermal system. Such transport as a sulfide complex, rather than a chloride complex, is consistent with the high activity of sulfur indicated by the mineral assemblages associated with the gold mineralization, the coexisting iron-poor sphalerite and the Ag-poor nature of gold grains. Because the $\mathrm{AuHS}^{\circ}$ complex is more stable than the $\mathrm{AuCl}_{2}{ }^{-}$complex under all the conditions considered here, gold is precipitated from the sulfide complex in both $\mathrm{Cu}$ - and $\mathrm{Zn}$-rich assemblages. Therefore, there is no need to rely on a low-temperature $\mathrm{Au}(\mathrm{HS})_{2}{ }^{-}$complex and a high-temperature $\mathrm{AuCl}_{2}{ }^{-}$complex for the respective $\mathrm{Zn}$-rich and $\mathrm{Cu}$-rich assemblages, as was proposed by Huston \& Large (1989) for ancient massive sulfide deposits. Indeed, for the conditions considered here, $\mathrm{Au}(\mathrm{OH})^{\circ}$ and not $\mathrm{AuCl}_{2}{ }^{-}$is the most stable complex at temperatures greater than $325^{\circ} \mathrm{C}$. This situation at Manus is probably common in all hydrothermal systems where fluids have a low $\mathrm{pH}$, such as at Lau Basin (Fouquet et al. 1993) and Suiyo Seamount (Ishibashi et al. 1994). Precipitation of gold from such a hydrothermal fluid is mainly accomplished by a decrease in $a\left(\mathrm{H}_{2} \mathrm{~S}\right)$ that may occur by mixing with seawater but, in shallow seafloor hydrothermal systems, may also result from loss of $\mathrm{H}_{2} \mathrm{~S}$ to a gas phase during boiling.

\section{ACKNOWLEDGEMENTS}

We are grateful to Anthony E. Williams-Jones for suggestions that improved an earlier version of this manuscript. Referees Ian R. Jonasson and J. Bruce Gemmell are thanked for their constructive comments and suggestions, which led to further improvements in the manuscript. The suggestions and careful editing of Robert F. Martin are gratefully acknowledged. This work was funded by a Natural Sciences and Engineering Research Council grant to SDS and by Ontario Graduate Student Scholarships to RM.

\section{REFERENCES}

ANDERSON, G.M. \& CRERAR, D.A. (1993): Thermodynamics in Geochemistry: the Equilibrium Model. Oxford University Press, Oxford, U.K.

AuZende, J.-M., Urabe, T. \& Shipboard Scientific Party (1996a): Submersible observation of tectonic, magmatic and hydrothermal activity in the Manus Basin (Papua New Guinea). Western Pacific Geophys. Meet. (Brisbane), W115 (abstr.).

\& (1996b): Cruise explores hydrothermal vents of the Manus Basin. Eos, Am. Geophys. Union Trans. 77, 244.

BARTON, P.B., JR. \& Toulmin, P., III (1964): The electrumtarnish method for the determination of the fugacity of sulfur in laboratory sulfide systems. Geochim. Cosmochim. Acta 28, 619-640.

\& (1966): Phase relations involving sphalerite in the Fe-Zn-S system. Econ. Geol. 61, 815-849.

BenEs, V., ScotT, S.D. \& Binns, R.A. (1994): Tectonics of rift propagation into a continental margin: western Woodlark Basin, Papua New Guinea. J. Geophys. Res. 99, 4439-4455.

Benning, L.G. \& Seward, T.M. (1996): Hydrosulphide complexing of $\mathrm{Au}(\mathrm{I})$ in hydrothermal solutions from 150 to $400^{\circ} \mathrm{C}$ and 500 to 1500 bars. Geochim. Cosmochim. Acta 60, 1849-1871.

BinNs, R.A. (1994): Submarine deposits of base and precious metals in Papua New Guinea. In Proc. PNG Geology, Exploration and Mining Conference. The Australasian Institute of Mining and Metallurgy, Melbourne, Australia (7183).

\& ScotT, S.D. (1993): Actively forming polymetallic sulfide deposits associated with felsic volcanic rocks in the eastern Manus back-arc basin, Papua New Guinea. Econ. Geol. 88, 2226-2236. 
\& GeMmell, J.B. (1997): Modern analogue of a mineral field: sea-floor hydrothermal activity hosted by felsic volcanic rocks in eastern Manus Basin, Papua New Guinea. SEG Neves Corvo Field Conf. (Lisbon), 33 (abstr.).

\& Wheller, G.E. (1991): Report on the PACLARK-V/PACMANUS-I cruise, RV Franklin, Woodlark and Manus Basins, Papua New Guinea. CSIRO Division of Exploration Geoscience, Restricted Rep. 263R.

Both, R., Crook, K., Taylor, B., Brogan, S., Chappell, B., Frankel, E., Lui, L., Sinton, J. \& Tiffin, D. (1986): Hydrothermal chimneys and associated fauna in the Manus back-arc basin, Papua New Guinea. Eos, Am. Geophys. Union, Trans. 67, 489-491 (abstr.).

Cole, D.R. \& DRummond, S.E. (1986): The effect of transport and boiling on $\mathrm{Ag} / \mathrm{Au}$ ratios in hydrothermal solutions: a preliminary assessment and implications for the formation of epithermal precious metal ore deposits. J. Geochem. Expl. 25, 45-80.

CoOK, N.L. \& Chryssoulis, S.L. (1990): Concentrations of "invisible gold" in the common sulfides. Can. Mineral. 28, $1-16$.

Craig, H., Craig, V.K. \& KIM, K.R. (1987b): PAPATUA Expedition 1: Hydrothermal vent surveys in back-arc basins: the Lau, N. Fiji, Woodlark, and Manus basins and Havre Trough. Eos, Am. Geophys. Union, Trans. 68, 100 (abstr.).

Horibe, Y., Farley, K.A., Welhan, J.A., Kim, K.R. \& Hey, R.N. (1987a): Hydrothermal vents in the Mariana Trough: results of the first Alvin dives. Eos, Am. Geophys. Union, Trans. 68, 1531 (abstr.).

\& PoredA, R. (1987): Studies of methane and helium in hydrothermal vent plumes, spreading axis basalts, and volcanic island lavas and gases in South West Pacific marginal basins. Scripps Institute of Oceanography Ref. 8714.

Fouquet, Y., Wafik, A., Cambon, P., Mevel, C., Meyer, G. \& GENTE, P. (1993): Tectonic setting and mineralogical and geochemical zonation in the Snake Pit sulfide deposit (MidAtlantic Ridge at $23^{\circ}$ N). Econ. Geol. 88, 2018-2036.

Gammons, C.H. \& WiLliams-Jones, A.E. (1995): The solubility of $\mathrm{Au}-\mathrm{Ag}$ alloy $+\mathrm{AgCl}$ in $\mathrm{HCl} / \mathrm{NaCl}$ solutions at $300^{\circ} \mathrm{C}$ : new data on the stability of gold(I) chloride complexes in hydrothermal fluids. Geochim. Cosmochim. Acta 59, 34533468 .

\& (1997): Chemical mobility of gold in the porphyry-epithermal environment. Econ. Geol. 92, 4559.

\& YU, Y. (1994): New data on the stability of gold(I) chloride complexes at $300^{\circ} \mathrm{C}$. Mineral. Mag. 58A, 309-310.
Gamo, T., Okamura, K., Charlou, J.L., Urabe, T., Auzende, J.M., Ishibashi, J., Shitashima, K., Chiba, H. \& ShipBOARD SCIENTIFIC PARTY (1997): Acidic and sulfate-rich hydrothermal fluids from the Manus Back-arc basin, Papua New Guinea. Geology 25, 139-142.

, SAKai, H., IShibashi, J., NAKAyAma, E., IsShIKI, K., Matsuura, H., Shitatshima, K., Takeuchi, K. \& Ohta, S. (1993): Hydrothermal plumes in the eastern Manus Basin, Bismark Sea: $\mathrm{CH}_{4}, \mathrm{Mn}, \mathrm{Al}$, and $\mathrm{pH}$ anomalies. Deep Sea Res. 40, 2335-2349.

Gena, K, Mizuta, T, Ishiyama, D., Matsubaya, O. \& Urabe, T. (1998): Mobility of major, minor and trace elements in basaltic andesite from a high sulfidation type of advanced argillic alteration in Desmos Caldera, Manus Basin, Papua New Guinea. Geol. Soc. Am., Program Abstr. 30, A-127.

Hannington, M.D., Herzig, P.M., Scott, S.D., Thompson, G. \& RonA, P.A. (1991): Comparative mineralogy and geochemistry of gold-bearing sulfide deposits on the midocean ridges. Marine Geol. 101, 217-248.

\& STOFFERs, P. (1999): Submarine epithermal deposits: modern examples from Iceland, New Zealand, and Papua New Guinea. Geol. Soc. Am., Program Abstr. 31, A-93.

Peter, J.M. \& SCotT, S.D. (1986), Gold in sea-floor polymetallic sulfide deposits. Econ. Geol. 81, 1867-1883.

\& ScotT, S.D. (1988): Mineralogy and geochemistry of a hydrothermal silica - sulfide - sulfate spire in the caldera of Axial Seamount, Juan de Fuca Ridge. Can. Mineral. 26, 603-625.

$\&$ (1989a) Gold mineralization in volcanogenic massive sulfides: implications of data from active hydrothermal vents on the modern sea floor. Econ. Geol., Monogr. 6, 491-507.

$\&$ (1989b) Sulfidation equilibria as guides to gold mineralization in volcanogenic massive sulfides: evidence from sulfide mineralogy and the composition of sphalerite. Econ. Geol. 84, 1978-1995.

, Thompson, G., RonA, P.A. \& ScotT, S.D. (1988): Gold and native copper in supergene sulphides from the Mid-Atlantic Ridge. Nature 333, 64-66.

Tivey, M.K., Larocque, A.C.L., Peterson, S. \& RonA, P.A. (1995): The occurrence of gold in sulfide deposits of the TAG hydrothermal field, Mid-Atlantic Ridge. Can. Mineral. 33, 1285-1310.

Hayashi, K.I. \& Онмото, H. (1991): Solubility of gold in $\mathrm{NaCl}-$ and $\mathrm{H}_{2} \mathrm{~S}$-bearing solutions at $250-350^{\circ} \mathrm{C}$. Geochim. Cosmochim. Acta 55, 2111-2126.

Helgeson, H.C. (1969): Thermodynamics of hydrothermal systems at elevated temperatures and pressures. Am. J. Sci. 267, 729-804. 
Herzig, P.M., Hannington, M.D., Fouquet, Y., von Stackelberg, U. \& Peterson, S. (1993): Gold-rich polymetallic sulfides from the Lau backarc and implications for the geochemistry of gold in sea-floor systems of the southwest Pacific. Econ. Geol. 88, 2182-2209.

Huston, D.L., Bottrill, R.S., Creelman, R.A., Zaw, K., RAMSDEN, T.R., RAND, S.W., GeMmell, J.B., JABlONSKI, W., Sie, S.H. \& LARGe, R.R. (1992): Geologic and geochemical controls on the mineralogy and grain size of gold-bearing phases, eastern Australian volcanic-hosted massive sulfide deposits. Econ. Geol. 87, 542-563.

\& LARGE, R.R. (1989): A chemical model for the concentration of gold in volcanogenic massive sulfide deposits. Ore Geol. Rev. 4, 171-200.

Hutchinson, R.W. (1990): Precious metals in massive base metal sulfide deposits. Geol. Rundsch. 79, 241-263.

Iizasa, K., Fiske, R.S., IshizuKa, O., Yuasa, M., Hashimoto, J., Ishibashi, J., NAKA, J., HoriI, Y., FuJIWARA, Y., IMAI, A. \& Koy Ama, S. (1999): A Kuroko-type polymetallic sulfide deposit in a submarine silicic caldera. Science, 283, 975-977.

Ishibashi, J.I., Tsunogai, U., Wakita, H., Watanabe, K., Kajimura, T., Shibata, A., Fujiwara, Y. \& Hashimoto, J. (1994): Chemical composition of hydrothermal fluids from the Suiyo and the Mokuyo Seamounts, Izu-Bonin Arc. JAMSTEC J. Deep Sea Res. 10, 89-97 (in Japanese, with Engl. abstr.).

\& URABE, T. (1995): Hydrothermal activity related to arc-backarc magmatism in the western Pacific. In Backarc Basins: Tectonics and Magmatism (B. Taylor, ed.). Plenum Press, New York, N,Y. (451-495).

Johnson, J.W., Oelkers, E.H. \& Helgeson, H.C. (1992): SUPCRT92: a software package for calculating the standard molal thermodynamic properties of minerals, gases, aqueous species, and reactions from 1 to 5000 bar and $0^{\circ} \mathrm{C}$ to $1000^{\circ} \mathrm{C}$. Computers Geosci. 18, 899-947.

Kharaka, Y.K., Gunter, W.D., Aggarwall, P.K., Perkins, E.H. \& DeBraAL, J.D. (1988): Solmineq.88: a computer program code for geochemical modeling of water-rock interactions. U.S. Geol. Surv., Water Investigations Rep. 88-4227.

LARGE, R.R. (1990): The gold-rich massive sulphide deposits of Tasmania. Geol. Rundsch. 79, 265-278.

Leistel, J.M., Marcoux, E., Deschamps, Y. \& Joubert, M. (1998): Antithetic behaviour of gold in the volcanogenic massive sulphide deposits of the Iberian Pyrite Belt. Mineral. Deposita 33, 82-97.

MARTINEZ, F. \& TAYLOR, B. (1996) Backarc spreading, rifting, and microplate rotation, between transform faults in the Manus Basin. Mar. Geophys. Res. 18, 203-224.
Moss, R. \& ScotT, S.D. (1996): Silver in sulfide chimneys and mounds from $13^{\circ} \mathrm{N}$ and $21^{\circ} \mathrm{N}$, East Pacific Rise. Can. Mineral. 34, 697-716.

MurPhy, P.J. \& MeYER, G. (1998): A gold-copper association in ultramafic-hosted hydrothermal sulfides from the MidAtlantic Ridge. Econ. Geol. 93, 1076-1083.

SAKAI, H. (1991): Expedition East Manus Basin hydrothermal field, Hakuro-Maru Cruise KH90-3, Leg 2. A brief summary report for SOPAC: South Pacific Applied Geoscience Commision. SOPAC Cruise Rep. 138.

ScotT, S.D. \& BARneS, H.L. (1971): Sphalerite geothermometry and geobarometry. Econ. Geol. 66, 653-669.

\& BinNs, R. (1995): Hydrothermal processes and contrasting styles of mineralization in the western Woodlark and eastern Manus basins of the western Pacific. In Hydrothermal Vents and Processes (L.M. Parson, C.L. Walker \& D.R. Dixon, eds.). Geol. Soc., Spec. Publ. 87, 191-205.

SEWARD, T.M. (1991): The hydrothermal geochemistry of gold. In Gold Metallogeny and Exploration (R.P. Foster, ed.). Blackie and Sons, Glasgow, U.K. (37-62).

\& BARNES, H.L. (1997): Metal transport by hydrothermal fluids. In Geochemistry of Hydrothermal Ore Deposits (H.L. Barnes, ed.; third edition). John Wiley \& Sons Inc., New York, N.Y. (435-486).

Sillitoe, R.H. (1989): Gold deposits in western Pacific island arcs: the magmatic connection. Econ. Geol., Monogr. 6, 274-291.

Suleimenov, O.M. \& SEwARD, T.M. (1997): A spectrophotometric study of hydrogen sulphide ionisation in aqueous solutions to $350^{\circ} \mathrm{C}$. Geochim. Cosmochim. Acta 61, 51875198 .

SverJensky, D.A., Shock, E.L. \& Helgeson, H.C. (1997): Prediction of the thermodynamic properties of aqueous metal complexes to $1000^{\circ} \mathrm{C}$ and $5 \mathrm{~kb}$. Geochim. Cosmochim. Acta 61, 1359-1412.

TUFAR, W. (1990): Modern hydrothermal activity, formation of complex massive sulfide deposits and associated vent communities in the Manus back-arc basin (Bismarck Sea, Papua New Guinea). Österreich. Geol. Gesellsch. Mitt. 82, 183-210.

WATANABE, K. \& KAJIMURA, T. (1994): The hydrothermal mineralization at Suiyo Seamount in the Izu-Ogasawara arc. $J$. Res. Geol. 44, 133-140 (in Japanese, with Engl. abstr.).

Zaw, K. \& LARGe, R.R. (1996): Petrology and geochemistry of sphalerite from the Cambrian VHMS deposits in the Rosebery-Hercules district, Western Tasmania: implications for gold mineralization and Devonian metamorphicmetasomatic processes. Mineral. Petrol. 57, 97-118. 
Zotov, A.V., BARANOVA, N.N., DAR'YINA, T.G. \& BANNYKH, L.M. (1991): The solubility of gold in aqueous chloride fluids at $350-500^{\circ} \mathrm{C}$ and $500-1500$ atm: thermodynamic parameters of $\mathrm{AuCl}_{2}-(\mathrm{sol})$ up to $750^{\circ} \mathrm{C}$ and $5000 \mathrm{~atm}$. Geochem. Int. 28(2), 63-71.
\& Kolotov, V.P. (1985): The stability of $\mathrm{AuOH}^{\circ}{ }_{\text {sol }}$ in water at $350-500^{\circ} \mathrm{C}$ and 500-1500 atm. Geochem. Int. 22(5), 156-161.

Received November 4, 2000, revised manuscript accepted July 8, 2001 